\title{
By-Product Feeds: Current Understanding and Future Perspectives
}

\author{
Kaili Yang ${ }^{1,2}$, Yiqing Qing ${ }^{1,2}$, Qifang Yu ${ }^{1,2}$, Xiaopeng Tang ${ }^{3}$, Gang Chen ${ }^{1,2}$, Rejun Fang ${ }^{1,2, *(\mathbb{D}) \text { and Hu Liu }}$ 1,2 (D) \\ 1 College of Animal Science and Technology, Hunan Agricultural University, No. 1 Nongda Road, Furong \\ District, Changsha 410128, China; ykelly@stu.hunau.edu.cn (K.Y.); qingyq@stu.hunau.edu.cn (Y.Q.); \\ zly0430@stu.hunau.edu.cn (Q.Y.); SX20190026@stu.hunau.edu.cn (G.C.); liuh2018@lzu.edu.cn (H.L.) \\ 2 Hunan Co-Innovation Center of Animal Production Safety, Changsha 410128, China \\ 3 School of Karst Science, Guizhou Normal University, Guiyang 550001, China; 201811001@gznu.edu.cn \\ * Correspondence: fangrj63@hunau.edu.cn; Tel.: +86-(0)731-8618177
}

Citation: Yang, K.; Qing, Y.; Yu, Q.; Tang, X.; Chen, G.; Fang, R.; Liu, H. By-Product Feeds: Current

Understanding and Future Perspectives. Agriculture 2021, 11, 207. https://doi.org/10.3390/ agriculture 11030207

Academic Editors: Vito Laudadio and Vincenzo Tufarelli

Received: 27 December 2020

Accepted: 22 February 2021

Published: 3 March 2021

Publisher's Note: MDPI stays neutral with regard to jurisdictional claims in published maps and institutional affiliations.

Copyright: (c) 2021 by the authors. Licensee MDPI, Basel, Switzerland. This article is an open access article distributed under the terms and conditions of the Creative Commons Attribution (CC BY) license (https:// creativecommons.org/licenses/by/ $4.0 /)$.

\begin{abstract}
Recently, industrial and agricultural by-products, resulting from crops, fruit and vegetable processing which can be used in animal diets have become a hot topic in the animal feed industry. This review focuses on the agro-industry by-products as feeds, not only for the nutritional values, but also for their nutricine contribution. In this review, we described the chemical composition of some by-products as feeds and their limiting factors in animal feeding.
\end{abstract}

Keywords: straws; residues; spent mushroom substrate; pig; hens; cattle; sheep

\section{Introduction}

With the continuously increasing global population, large margin foods are needed and it is estimated that agricultural production should also be improved by $70-100 \%$ to meet global food demand in the future [1]. Unfortunately, more than 820 million people suffered from hunger in 2018, and about 2 billion people undergo moderate or severe food insecurity globally [2]. However, the Food and Agriculture Organization (FAO) has estimated that approximately one-third of the food produced globally for human consumption is lost or wasted, representing a significant loss of the resources spent making, processing and transporting food and a threat to food security [3]. The reduction of food waste is, therefore, a potential strategy for closing the gap between the supply and demand of food.

Based on corn and soybean meal as energy and protein sources, livestock provides meat, eggs, milk (as shown in Figure 1) and so on, contributing 1/5 of protein intake to human beings [4]. Consequently, livestock production between 2010 and 2025 has been projected to expand by $21 \%$ [5]. If feed efficiency remains the same, this expected expansion will require the world feed supply to increase from 6.0 to 7.3 billion tons of dry matter [6]. Competition between humans and animals for grains (corns, wheat, bean and others) is increasing. Therefore, global food security is at risk due to increasing pressure on natural resources threatening food systems' sustainability in general. It has become imperative to consider the development of new ingredients especially non-conventional feedstuffs which might be used in the animal feed industry. Initial estimates made by FAO for the Food Loss Index indicate that around $14 \%$ of the world's food is lost from post-harvest up to (but not including) the retail level [3]. Moreover, halophytes [7], straw [8], and residues [9] also can be used as feedstuffs.

By-product feedstuffs can be categorized into different classifications including stalks and residues. The residues contain several categories, such as by-products from residues of fruit and vegetable, by-products from grain- and legume-milling industry and oil industry. The agro-industry by-products are rich in nutrients, and they can reduce costs for animal products. The sharp increase in the processed foods will make industrial by-products and co-products more available. Systems of feedstuff manufacture from wastes make a 
vertical, mutually complemented synthesis of animal production feasible and resolve the problem of waste and environmental pollution. Moreover, the utilization of new typical agro-industry by-products like fruit and vegetable by-products as feeds which supports sustainable development in feedstuffs. These agro-industry by-products will be of real value as an outlet for the leading products from which they have been derived and relieved food crisis to a certain degree. This review discusses and summarizes nutrition and the methods to improve the quality of agro-industry by-products as unconventional feeds.

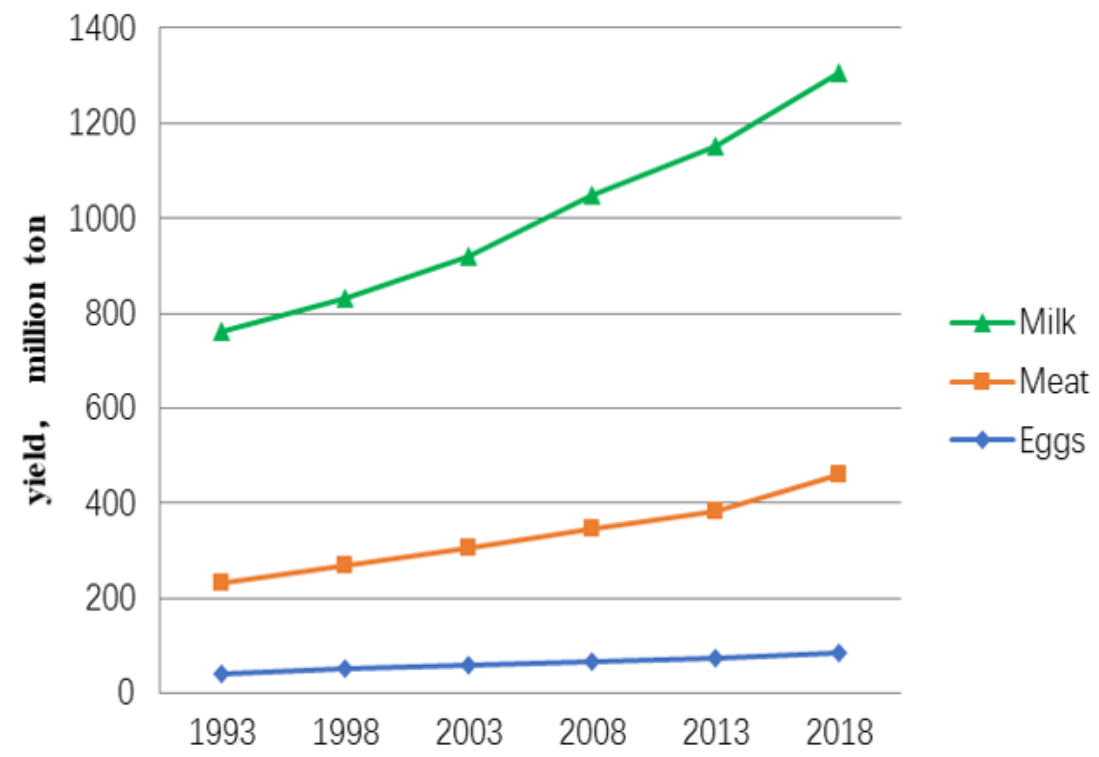

Figure 1. The yield of milk, meat, eggs in the past 30 years (FAO).

\section{The Nutritional Components of the Agro-Industry By-Products}

Most agro-industry by-products as feedstuffs are enriched in protein, fiber (as shown in Table 1), and other nutricines, which play vital roles in the feed industry's ingredients [10-12]. Plenty of agro-industry by-product protein sources have been used in animal feed [13].

Table 1. The chemical composition of straws and residues from food (\%).

\begin{tabular}{|c|c|c|c|c|c|c|c|c|}
\hline Items & DM & $\mathrm{CP}$ & NDF & ADF & CF & EE & Ash & Reference \\
\hline \multicolumn{9}{|l|}{ Stalks } \\
\hline Corn & 86.60 & 5.90 & 74.10 & 39.70 & - & - & - & Wang et al., 2014 [14] \\
\hline Rice & 89.90 & 7.26 & 71.30 & 44.80 & - & 1.46 & - & Wei et al., 2018 [15] \\
\hline Wheat & 88.60 & 5.45 & 81.40 & 58.10 & - & 1.14 & - & Wei et al., 2018 [15] \\
\hline Chickpea & 89.60 & 6.50 & 69.40 & 51.60 & 39.00 & 1.20 & 6.80 & Bampidis et al., 2011 [16] \\
\hline Cotton & - & 6.85 & 58.86 & 40.60 & - & 2.39 & 7.77 & Zhang et al., 2018 [17] \\
\hline Pepper & - & 15.77 & 41.16 & 37.43 & - & - & - & Zhou et al., 2016 [18] \\
\hline Soybean & 94.62 & 3.67 & 67.34 & 51.162 & - & - & 3.69 & Shen et al., 2019 [19] \\
\hline Rape & 93.62 & 5.79 & 67.87 & 55.52 & - & 2.51 & 7.58 & Lan et al., 2019 [20] \\
\hline Fennel & 92.17 & 4.33 & - & - & 36.41 & 1.00 & - & Yuan et al., 2018 [21] \\
\hline Sunflower & 90.73 & 5.72 & 53.09 & - & 30.15 & 0.89 & - & Yuan et al., 2018 [21] \\
\hline \multicolumn{9}{|l|}{ Residues } \\
\hline Soya-bean Meal & 93.85 & 44.56 & 13.84 & 7.35 & 5.60 & 5.69 & 5.70 & NRC, 2012 [22] \\
\hline Rapeseed Meal & 93.11 & 35.19 & 23.77 & 17.57 & 9.77 & 9.97 & 6.39 & NRC, 2012 [22] \\
\hline Cottonseed Meal & 90.69 & 39.22 & 25.15 & 17.92 & 13.96 & 5.50 & 6.39 & NRC, 2012 [22] \\
\hline Fishmeal & 93.70 & 63.28 & - & - & 0.24 & 9.71 & 16.07 & NRC, 2012 [22] \\
\hline Blood Meal & 93.23 & 88.65 & - & - & - & 1.45 & 5.82 & NRC, 2012 [22] \\
\hline Feather Meal & 94.24 & 80.90 & - & - & - & 5.97 & 5.08 & NRC, 2012 [22] \\
\hline Meat Meal & 96.12 & 56.40 & 31.60 & 8.30 & - & 11.09 & 21.59 & NRC, 2012 [22] \\
\hline Apple Pomace & 92.35 & 6.62 & 39.03 & 20.78 & 14.48 & 5.53 & - & Xiong et al., 2020 [23] \\
\hline
\end{tabular}


Table 1. Cont

\begin{tabular}{|c|c|c|c|c|c|c|c|c|}
\hline Items & DM & $\mathrm{CP}$ & NDF & ADF & $\mathrm{CF}$ & EE & Ash & Reference \\
\hline Mango Pulps & 92.06 & 16.38 & - & - & 18.90 & 5.50 & 6.43 & Pluschke et al.,2018 [24] \\
\hline Orange Pulp & 22.10 & 15.10 & 26.50 & 17.20 & 7.70 & 19.10 & - & Minguez et al., 2018 [25] \\
\hline Potato Pulp & 100.00 & 8.21 & 22.30 & 17.53 & - & - & 4.05 & Shen et al., 2019 [19] \\
\hline Fennel Shell & 91.17 & 7.61 & - & - & 23.31 & 2.92 & - & Yuan et al., 2018 [21] \\
\hline Sunflower Plate & 89.63 & 11.84 & 23.51 & - & 12.48 & 2.13 & - & Yuan et al., 2018 [21] \\
\hline Cotton Shell & 91.57 & 10.53 & 45.77 & - & 53.52 & 2.04 & - & Yuan et al., 2018 [21] \\
\hline Grape Seed & 97.40 & 9.30 & 53.90 & - & - & 10.90 & 2.70 & Correddu et al., 2015 [26] \\
\hline Winery Sediment & 31.20 & 2.80 & 6.40 & 4.30 & - & 28.00 & 21.40 & Ishida et al., 2015 [27] \\
\hline Olive Cake & 94.70 & 7.90 & 58.4 & 45.9 & - & 9.20 & 13.60 & Abbeddou et al., 2011 [28] \\
\hline Cassava Residue & 90.16 & 2.58 & 75.34 & 24.48 & - & 0.22 & - & Lv et al.,2017 [29] \\
\hline Bean Curd Residue(Air-dried) & 93.25 & 18.14 & 42.99 & 28.69 & - & 3.34 & - & Lv et al.,2017 [29] \\
\hline Pistachio & 90.00 & 15.30 & 25.90 & - & - & 5.80 & - & Ghasemi et al., 2012 [30] \\
\hline Pomegranate Pulp & 91.20 & 6.90 & 31.40 & 22.80 & - & 2.60 & 3.60 & Valenti et al., 2019 [31] \\
\hline Citrus Pulp & 90.40 & 7.70 & 19.40 & 12.80 & - & 4.90 & 16.80 & Fegeros et al., 1995 [32] \\
\hline Exhausted Myrtle Berries & 97.00 & 8.00 & 67.00 & 53.30 & - & 2.60 & 9.00 & Castrkca et al., 2019 [33] \\
\hline Coffee Grounds & 91.10 & 11.80 & - & - & 42.50 & 23.1 & 7.00 & Campbell et al., 1976 [34] \\
\hline Pumpkin Peel & - & 1.65 & - & - & 2.240 & 0.86 & - & Valdez-Arjona et al.,2019 [35] \\
\hline Pumpkin Pulp & - & 1.13 & - & - & 1.09 & 0.42 & - & Valdez-Arjona et al.,2019 [35] \\
\hline Pumpkin Seed & - & 27.50 & - & - & 16.20 & 52.4 & - & Valdez-Arjona et al.,2019 [35] \\
\hline Bitter Gourd & 9.27 & $22.30^{\mathrm{a}}$ & $45.10^{\mathrm{a}}$ & $35.80^{\mathrm{a}}$ & - & - & - & Das et al., 2018 [36] \\
\hline Brinjal & 7.85 & $17.2^{\mathrm{a}}$ & $47.20^{\mathrm{a}}$ & $42.10^{\mathrm{a}}$ & - & - & - & Das et al., 2018 [36] \\
\hline Cabbage & 9.97 & $17.3^{\mathrm{a}}$ & $33.70^{\mathrm{a}}$ & $20.90^{\mathrm{a}}$ & - & - & - & Das et al., 2018 [36] \\
\hline Cauliflower & 10.40 & $27.0^{\mathrm{a}}$ & $58.40^{\mathrm{a}}$ & $30.40^{\mathrm{a}}$ & - & - & - & Das et al., 2018 [36] \\
\hline Snake Gourd & 4.30 & $18.4^{\mathrm{a}}$ & $48.0^{\mathrm{a}}$ & $37.70^{\mathrm{a}}$ & - & - & - & Das et al., 2018 [36] \\
\hline Sweet Gourd & 5.40 & $9.40^{\mathrm{a}}$ & $43.10^{\mathrm{a}}$ & $31.20^{\mathrm{a}}$ & - & - & - & Das et al., 2018 [36] \\
\hline Tomato & 5.20 & $20.0^{\mathrm{a}}$ & $50.40^{a}$ & $36.90^{\mathrm{a}}$ & - & - & - & Das et al., 2018 [36] \\
\hline Cucumber & 4.00 & $20.1^{\mathrm{a}}$ & $42.70^{\mathrm{a}}$ & $37.50^{\mathrm{a}}$ & - & - & - & Das et al., 2018 [36] \\
\hline Sugar Cane Residues & 85.04 & 10.62 & 31.58 & 27.77 & 18.12 & 1.50 & 12.82 & Zhang et al., 2017 [37] \\
\hline $\begin{array}{l}\text { Pleurotus Eryngii Spent } \\
\text { Mushroom Substrate }\end{array}$ & 93.12 & 12.34 & 64.33 & 44.41 & - & 0.22 & 14.22 & Li et al., 2019 [38] \\
\hline Ganoderma Lucidum Bran & 90.07 & 17.77 & 40.83 & 28.73 & 14.76 & 9.65 & 14.09 & Zhang et al., 2017 [37] \\
\hline Faba Bean & 89.8 & 4.9 & 78.80 & 69.10 & - & - & 5.50 & Wegi et al., 2018 [39] \\
\hline Phragmites Hay & - & $7.18^{\mathrm{a}}$ & $73.05^{\mathrm{a}}$ & $38.11^{\mathrm{a}}$ & - & $2.59^{a}$ & $8.05^{\mathrm{a}}$ & Zhang, 2019 [40] \\
\hline Mulberry Leaves & - & 18.08 & 43.23 & 29.87 & 24.34 & 0.82 & 9.53 & Cai, 2019 [41] \\
\hline Bottle Gourd Leaf & 8.10 & 33.6 & - & - & 11.20 & 4.20 & 18.2 & Hossain, 2016 [42] \\
\hline Castor Bean Leaf & 24.20 & 21.0 & - & - & 25.00 & 1.60 & 9.30 & Hossain, 2016 [42] \\
\hline Broussonetia Papyrifera & 91.12 & 12.80 & 46.91 & 35.73 & - & 3.50 & 8.84 & Hao et al.,2020 [43] \\
\hline Leucagena & 32.00 & 20.5 & 31.60 & - & - & - & 6.40 & $\begin{array}{l}\text { Halmemies-Beauchet-Filleau et al., } \\
\qquad 2018 \text { [44] }\end{array}$ \\
\hline Moringa & 33.00 & 25.1 & 21.90 & - & - & - & 11.50 & $\begin{array}{l}\text { Halmemies-Beauchet-Filleau et al., } \\
\qquad 2018 \text { [44] }\end{array}$ \\
\hline Pine Bark & - & 2.8 & 66.70 & - & - & 4.70 & 2.20 & $\begin{array}{l}\text { Halmemies-Beauchet-Filleau et al., } \\
\qquad 2018 \text { [44] }\end{array}$ \\
\hline Willow & 26.40 & 16.7 & 57.30 & - & - & - & 7.10 & $\begin{array}{l}\text { Halmemies-Beauchet-Filleau et al., } \\
\qquad 2018 \text { [44] }\end{array}$ \\
\hline
\end{tabular}

Note: DM: Dry matter; CP: Crude protein; NDF: Neutral detergent fiber; ADF: Acid detergent fiber; CF: Crude fiber; EE: Ether extract;

a: Based on DM.

\subsection{Stalks}

The structural portion of most plants, such as the stalks, leaves, and stems, are high in acid detergent fiber (ADF) and neutral detergent fiber (NDF) but low in protein and minerals [45]. Some dietary fiber may be essential for young ruminants (like calves) to sustain attrition in their rumen and keep away from abnormal growth of the rumen [46]. As feedstuff, straw is a by-product of crops, including rice, wheat, corn, and vegetables [47]. For example, millet straw is a crucial coarse fodder provenience for ruminants in many areas [47]. Straws can be not only supplemented with grains or by-products of grains but also as individual ingredients. Stalks are mixtures of pasture used in ruminant feedstuff frequently and the raw materials of ensiling [48]. Chen et al. (2020) investigated that the combinational utilization of millet straw and corn straw could accelerate the metabolism ability of blood biological chemistry in fattening lambs. The growth performance of fattening lamb was improved by the substitute of 50\% corn straw with millet straw [48]. Silage-formed stalks include a moderate quantity of protein (9.3-13.0\%) and a high content 
of NDF (48-59\%), which may be a possible source of roughage for ruminant animals [49,50]. Straw is rarely used for monogastric animal feeding. Few research studies investigated that straws were provided to pigs, which could decrease gastric ulcers [51]. In Jensen et al.'s study, the straws were delivered to pigs on a concrete floor, which increased the daily weight gain, the improvement of intestinal tract health and increased stimulation of exploratory behavior with the straws provided need to explore [52]. Ruminants traditionally grazed on pastures, however, with more intensive systems, pasture availability and grazing as a source of nutrients is decreasing. One of the effective ways is that straws are used as feed to ruminant animals. Feeding protein supplements is one of the most expensive and limiting feed sources $[13,53]$. Some stalks are with typically high moisture content, leading to a decrease in the shelf-life and making their collection and incorporation in animal feed more difficult. In the past years, crop straws fired on the farm not only have significantly impaired air quality but have also wasted sources [54]. Many researchers have been attempting to find methods to improve the nutrition of stalks, such as ensiling. In general, the utilization of stalks, which are human-inedible resources, as a source of animal feedstuff would help to solve the problem of feed inadequacy in a way, potentially decreasing feed costs, and reducing the relevant problems of waste resources.

\subsection{Residues}

The residue feeds contain agro-industry by-products of plants (oil-seed-meals, plant shell, seed, fruit pulp, fruit pomace, and others), animal (whey, fishmeal, meat and bone meal, blood meal, and so on), and mushroom substrate. The NDF and ADF of residue feeds are lower, while crude protein is higher than straw. Most residues are abundant with crude protein, dietary fiber and phenolic compounds. Agro-industry by-products as feedstuff of plant include conventional feed (soya bean meal, cottonseed meal, rapeseed meal, and others) and unconventional (oil-seed-meals, plant shell, seed, fruit pulp, fruit pomace, etc.) feed.

Soya-bean meal is mainly used in the livestock feed as a protein source, moreover, it is palatable. However, people are exploring a protein substitute that will displace soya-bean in the livestock diets because of its dependence on imports and high prices [55]. Rapeseed meal and cottonseed meal, oil industry by-products, are generally acknowledged as alternative protein feed for animals. Rapeseed meal is a feed component with huge economic potential. It is the second used raw protein material worldwide (after soybean meal) in feeding livestock [56]. The crude protein of rapeseed meal can vary from $33.9-36 \%$ of dry matter and this protein supplies less lysine than soybean meal protein but contains more sulfur-containing amino acids [56], and this material is restricted as fodder in livestock due to high levels of anti-nutritional ingredients (particularly tannins, glucosinolates and phytic acid). The utilization of cottonseed meal as feedstuff is also limited because of the presence of high free gossypol (a toxic polyphenolic compound), crude fiber and low lysine level [57].

Agro-industry by-products as unconventional feed sources can be defined as those not traditionally used in animal feeding and commercially prepared feedstuffs for farm animals. The agro-industry by-products as unconventional feedstuffs consist of various food resources, such as palm press fiber (oil palm by-products), by-products from the processing of sugar, cereal grains, citrus fruits and vegetables from the food processing for human consumption [58]. Nutritional ingredients of partial agro-industry by-products as unconventional feeds are listed in Table 1. Agro-industry by-products as unconventional feedstuffs have been exploited for farm animals mainly including peanut meal, olive oil cake, mulberry leaves, orange pulp, as shown in Table 1. Concerning the crude protein, contents and large values can be observed for all by-products or new feed ingredients like broussonetia papyrifera, mulberry leaves or mango pulps. Fruit pomace also contains bioactive ingredients including vitamins, polyphenols (especially anthocyanins), dietary fiber, and essential unsaturated fatty acids [59]. Fruit pulp is a good source of the beneficial active compounds: gallic acid, phenolic compounds (anthocyanins, etc.) [60], carotenoids, and dietary fiber [61], and so on. Moreover, dietary fiber is described as supporting 
laxation, attenuating blood glucose responses and assisting with cholesterol-lowering, and influencing gut microbiota [62]. The biological activities of polyphenols have been primarily observed and proved the antioxidant abilities, positive consequences on health like antiinflammatory effects $[63,64]$. These natural compounds were considered and they can replace antibiotics in the agro-industry by-product as feeds are used all over the world [12]. In the past few decades, a hot point to develop functional foods has emerged, which contains diverse ingredients (protein, specific fatty acids, selenium-riched, low cholesterol), protecting chronic diseases of cancer $[65,66]$. Khan et al. (2012) indicated that flaxseed cake improved omega-3 fatty acid and vitamin of eggs [67]. However, particularly high protein content of agro-industry by-products has much more phenols including chlorogenic and caffeic acids, which decreases its nutritional value by combining with proteins, particularly to essential amino acids such as lysine and methionine [68]. Hence, seeking methods to improve the nutritional value of agro-industry by-products is indispensable.

Feedstuffs of animal-by-product are generally better than that of plants for the health and performance of livestock and poultry because of the greater quantity of proteinogenic amino acids (AAs) and higher quality (the proportions and digestibility of AAs) [69]. Moreover, animal-derived feedstuffs contain taurine, creatine and creatine phosphate that are effective anti-oxidants and partake in energy metabolism in the brain, skeletal muscle, heart, and gonads of animals [70]. Additionally, animal-derived feedstuffs may involve polyamines that are fundamental for DNA and protein syntheses in most animals [71]. Common animal-by-product feedstuffs contain fishmeal, feather meal, blood meal, meat and bone meal, and meat meal. Among animal-by-product feedstuffs, fishmeal was most used which generally exchanged at $65 \%$ crude protein, but the crude protein content can change from $57 \%$ to $77 \%$, relying on the species of fish processed [69]. Varieties of fish species can be used in fishmeal, while the most general is Menhaden that occupies about $90 \%$ of U.S. fishmeal production [72]. Feather meal is superior to soybean meal in total cysteine, valine, and threonine content. It is cheaper as a protein source. On the other hand, feather meal has not been widely used as a protein source in livestock and poultry diets due to the modifiability in quality and digestibility [73]. Animal-by-products are not widely used as protein sources in feedstuffs compared with plant-by-products. One of the most important reasons is that if pathogenic bacteria would be unsuccessful in being inactivated during the processing of animal carcasses under these altered conditions, and that feeding such polluted material to animals spread the pathogen to animals, causing disease [74]. By-products of animals as protein sources in diets for livestock are forbidden in Europe (European Commission Decisions No. 98/272/CE and 2000/374/CE). According to the report of Hahn, the following steps of the processing of animal meal include that cutting up the carcasses, sterilization of the material, drying the material to a water content of around $5 \%$, removal of fat, and grinding and sieving of the material. Every step should be performed carefully to guarantee the quality of animal meal [75].

A mushroom substrate is a co-product of composted organic medium from the mushroom growth process which is usually the production of renewable agricultural residues including sugarcane bagasse, cottonseed meal, cocoa shells, oil palm empty fruit bunch, and others [76]. After mushrooms are harvested, the mushroom substrates which are enriched in cellulose, lignin and protein could be more easily digested by animals due to enzymolysis of mushroom cultivating [77]. The mushroom substrate contains many bioactive ingredients such as secondary metabolites, extracellular enzymes and carbohydrates produced [78]. The mushrooms industry is one of the incredible drivers in the world and has plentiful mushroom substrates which face storage and disposal issues [79]. One method to solve the problem is to feed animals with the mushroom substrate.

It is worth noting that the chemical compositions of by-products depend on soil varieties, agroclimatic conditions, stage of ripening, or other facts [35,43,80]. Several factors, including protein concentration and its biological value, digestibility, level of energy, fats and carbohydrates, concentration of amino acids, vitamin and mineral, and the amount of fiber and the existence of toxic substances, influence the quality of by-product feedstuffs. 


\section{The Measures to Improve Agro-Industry By-Product Quality}

Lots of agro-industry by-products have low quality, and some of them contain antinutritional factors (Table 2) which influence feed palatability, digestibility, and impaired animal production performance [81-83]. Bampidis et al. (2011) reviewed that chickpeas contain a variety of secondary compounds (protease and amylase inhibitors, lectins, polyphenols and oligosaccharides) which impair nutrient absorption on animal health and growth [16]. The agro-industry by-products as feeds are also limited by high fiber [84,85]. Ruminants generally can endure a much higher content of toxic factors than nonruminants [86]. However, there are new and available technologies emerging to degrade or remove anti-nutritional factors and improve the quality of by-products.

Table 2. Anti-nutritional factors on agro-industry by-products ingredients.

\begin{tabular}{cc}
\hline Anti-Nutritional Factors & Sources \\
\hline Protease inhibitors & Beans \\
Lectin & Beans, Gramineae, Solanaceae, Amaryllidaceae \\
Tannin & J. St.-Hil. \\
Non-starch polysaccharide (NSP) & Sorghum, Brassica napus L, beans \\
Gaseous distention factor & All plants \\
Antigenic protein & Beans \\
\hline
\end{tabular}

\subsection{Physical Processing}

Physical processing, including crushing, peeling, soaking, extruding, and expanding, does not have effects on the chemical composition of biomass, but changes physical characteristics such as surface area, bulk density, and specific porosity [87]. Physical processing is used as pretreatment for destroying the by-products' stubborn structure to facilitate the following processing more effectively. As Akobi et al. indicated, the extrusion decreased particle size and crystallinity and enhanced surface area of biomass sugar availability of lignocellulosic [88]. Heat-treating rapeseed products is a straightforward, effective way to deactivate myrosinase. This approach, currently the most popular, degrades up to $70 \%$ of the glucosinolates contained in rapeseed meal [56].

\subsection{Chemical Processing}

Chemical processing includes alkalinization, acidification, oxidation and ammonification. Alkalinization, acidification and oxidation have not been widely used because of pollution, high cost, etc. Ammoniation is commonly used in chemical processing. However, liquid ammonia and ammonia water transport are very inconvenient. Additionally, the ammonia loss rate is high, and there is a certain degree of insecurity. However, the methods mentioned can be combined in their utilization. For example, lignocellulose is a mass of content in straws of about $80-95 \%$. It has bad hydrolysis performance which hinders the absorption and degradation of energy recovery and volatile concrete degradation which can treatment with mesophilic anaerobic digestion and urea plus nitrate pretreatment $[89,90]$.

\subsection{Biological Processing}

Biological processes include enzymolysis technology, microbial fermentation, and so on. The enzymes commonly used by the feed industry are the glycanases involved in the splitting decomposition of NSP in viscous cereals (wheat and triticale) and microbial phytases that aim at phytate-complexes in plant components [91]. Moreover, relatively abundant literature examples (papers and patents) have introduced the utilization of typical enzymatic hydrolysis treatments (proteases, glycosyl hydrolases) on by-products for enhancing the nutritional value and digestibility of protein hydrolysates [92]. Microbial fermentation can improve the nutritional ingredient of particular by-products [93]. Fermentation can enrich the nutrition of residues by biotransformation which implements several microorganisms, mainly Bacillus, Saccharomycetes, fungi, Lactobacillus spp [94,95]. Fermentation enhanced 
crude protein concentration and other nutriment but reduced many anti-nutritional factors, crude fiber content and toxic ingredients. Organic acid, several amino acids and metabolite of Okara were increased by fermentation [96]. Wang et al. (2020) showed that the crude protein content of corn straw reached the maximum value of $13.23 \%$ when fermented by Trichoderma koningiopsis, Phanerochaete chrysosporium and Saccharomyces cerevisiae [97] and Wu et al. (2020) reported that the corn stalk fermented by fungi and enzyme mix (cellulose, xylanase and Phanerochaete chrysosporium were $0.2 \mathrm{~g} / \mathrm{kg}, 0.1 \mathrm{~g} / \mathrm{kg}$ and $20 \%$ respectively) were degradable, with NDF and ADF to $51.61 \%$ (vs. $67.44 \%$ ) and $31.77 \%$ (vs. $39.79 \%$ ) [98]. Zhu et al. (2018) showed the content of 17 kinds of amino acids and total AA content was increased in tea residue when fermentation by Aspergillus niger. Moreover, the total tanning, NDF, ADF were decreased to $2.42 \%$ (vs. $11.63 \%$ ), $32.96 \%$ (vs. $39.85 \%$ ) and $12.28 \%$ (vs. $15.70 \%$ ) respectively [99]. The ensiling process is an available conservation technology that is known to acidify biomass, and it restrains the development of spoilage bacteria, thus providing safe and long-term preservation for humid fodder [100]. Inoculation with lactic acid bacteria (LAB) or supplementation with easily fermentable carbohydrates (readily metabolizable by LAB) like molasses, certified to be successful in increasing the availability of the ensiling process. This supplies an additional source of simple sugars for the growth and multiplication of $\mathrm{LAB}$, thereby accelerating the silage acidification and avoiding microbial deterioration, especially when the ensiling biomass has a low concentration of soluble carbohydrates. In general, agro-industry by-products as feeds can be improved by fermented, silage, enzyme and other ways [101].

The feedstuffs are commonly manufactured by a combination of technologies to improve nutrition. For example, lignocellulosic biomass can be changed into fermentable sugars. This process needs pretreatment to decrease the recalcitrance of lignocellulosic biomass by opening or partially breaking up the recalcitrant structure to enhance the enzymes' accessibility to the cellulose during the enzymatic hydrolysis step. These pretreatment methods are usually divided into physical, chemical, physical-chemical and biological categories, such as steam explosion, dilute acid pretreatment, organosol pretreatment, and alkali pretreatment [86].

\section{The Application of Agro-Industry By-Products as Feeds in Animals}

There is a considerable amount of research studies on the roles of agro-industry by-products as feeds in animals. Moreover, agro-industry by-products as feeds have an influence on growth performance, immune function and product quality. However, it is quite difficult and risky to clarify the contribution of each by-product on feed intake and animal performance by considering the attribution of nutricines, due to the complexity of chemical compositions in by-products. In addition, several agro-industry by-products have negative effects when supplied too much in the feed.

\subsection{The Application of Agro-Industry By-Products as Feeds in Monogastric Animals}

The applications of agro-industry by-products as feeds in monogastric animals (particularly pigs and poultry) are especially prudent for their direct competition with humans for edible energy and protein sources due to the common diet is corn-soybean in the pig and poultry industry. Monogastric animal feeding is more and more challenged by feedstuff in the diets, immune traits, and meat quality. Currently, numerous studies focus on feedstuffs from agricultural by-products on pigs and poultry [102,103]. Moreover, over the last decade, the interest in entirely natural, plant-derived antioxidants has increased greatly $[104,105]$. Many agro-industry by-products as feeds can improve the feed conversion ratio, body weight, antioxidant capacity, immunity, gut morphology and intestinal microflora of pigs $[78,106]$ and poultry $[37,107]$. The research studies of agro-industry by-products as feedings of pigs and poultry are shown in the following subparagraphs. 


\subsubsection{Pigs}

Agro-industry by-products as pig feedings can enhance growth performance, meat quality of piglets and growing pigs, and improve production performance, milk, and quality of sows. Dong et al. (2019) assessed the nutrient profiles, the apparent total tract digestibility of nutrients, digestible energy, and metabolizable values of the five feeds: highland barley, buckwheat, glutinous broomcorn millet, non-glutinous broomcorn millet, and Chinese naked oat in the feeding of growing pigs. The results indicated that the five feeds, and particularly the broomcorn millets, could replace the corn in growing pig diets [108]. Numerous beneficial effects of mulberry were identified, including antibacterial and antitumor effects, reducing blood sugar, and improving immunity [109]. Several studies reported that mulberry and Broussonetia papyrifera are effective feedstuffs to improve meat quality and the chemical composition of muscle without negative effects on growth performance $[110,111]$. Most experiments of dietary fiber mainly on the sows confirmed improve production performance, milk quality, immunity traits, and sow's welfare [112-114]. The inulin and cellulose as fiber sources were used in the above studies. Several research studies reported the use of brans or straws which have high fiber content and low cost as fiber in sow production but few studies are observed on the finishing pig. Fan et al. (2020) showed that rice bran replacing corn decreased the inflammatory biomarkers of serum and have the potential function in modulating the intestinal barrier by upregulating the mRNA expression levels of MUC2 and downregulating Nrf2, NQO1, and HO-1 in the colon [115]. More attention should be paid to the fiber source from agro-industry by-products. The results of agro-industry by-products used in pigs are partly demonstrated in Table 3. The research studies of abnormal by-product feeds of oil-seed-meals (like olive cake processing waste, cassava peel meal, brewers dried grain, mango pulp) were supplied for the diets of pigs, and could decrease the backfat thickness and intramuscular fat [116], reduce Insulin-like growth factor (IG-2) expression in liver and duodenum [117], and increase starch and protein digestion [24]. By-product feeds of forestry decreased meat $b^{*}$ value, increased, CP and concentrations of Ala, Thr, Ile, Lys and Pro in longissimus thoracis, increased final BW, ADFI and ADG, decreased F/G ratio, improved slaughter weight, carcass weight, and carcass yield and meat a* value, decreased shear force, drip loss, such as mulberry leaf and moringa oleifera [106].

Most agro-industry by-products are of lower quality as pig diet feedstuffs. However, they can be improved through chemical, physical and especially biological technology. Rho et al. (2018) investigated treating corn and DDGS with a mixture of $\beta$-glucanase and xylanases improved feed efficiency in growing pigs [118]. Sehm et al. (2007) concluded that the flavonoid-rich feeding regiment (polyphenol-rich apple pomace or red wine pomace) has positive effects on villi morphology and gut-associated lymphoid tissue activation, improving pig health [119]. Fang et al. (2016) supplemented apple pomace-mix silage (APMS) to neutered male pigs, and the results demonstrated no difference in average daily gain (ADG), carcass weight, backfat thickness or dressing ration with the control group, but average daily feed intake (ADFI) was lower and feed efficiency was higher when feeding APMS. Moreover, the APMS improved the moisture, linoleic acid, linolenic acid and arachidic acid and decreased the water holding capacity, plamitic acid, palmitoleic acid, and heptadecenoic acid content [120]. 
Table 3. Applications of agro-industry by-products as feeds in pigs.

\begin{tabular}{|c|c|c|c|c|}
\hline Items & Levels & Monogastric & Main Influences & References \\
\hline $\begin{array}{c}\text { Olive Cake Processing } \\
\text { Waste }\end{array}$ & $5,10 \%$ & Growing-finishing pig & $\begin{array}{c}\text { Decreased backfat thickness and } \\
\text { intramuscular fat and modified } \\
\text { their fatty acid composition, } \\
\text { increasing the concentration of } \\
\text { MUFA and PUFA and improving } \\
\text { quality indices. }\end{array}$ & Liotta et al., 2019 [116] \\
\hline $\begin{array}{l}\text { Brewers dried grain, } \\
\text { cassava peel meal, } \\
\text { Plantain peel meal, } \\
\text { corn } \\
\text { husk meal }\end{array}$ & $35 \%$ & Growing pigs & $\begin{array}{l}\text { Decreased Insulin-like growth } \\
\text { factors (IG-2) expression in liver } \\
\text { and duodenum }\end{array}$ & Sorhue et al., 2020 [117] \\
\hline Mango pulp & $15 \%$ & Grower pigs & $\begin{array}{l}\text { Increased starch and protein } \\
\text { digestion to a certain extent }\end{array}$ & $\begin{array}{l}\text { Pluschke et al., } 2018 \\
\text { [24] }\end{array}$ \\
\hline Moringa oleifera & $4 \%$ & Finishing pig & $\begin{array}{c}\text { Decreased meat } b^{*} \text { value, } \\
\text { MyHCIIx mRNA levels, increased } \\
\text { MyHCIIa, CP and concentrations } \\
\text { of Ala, Thr, Ile, Lys and Pro in } \\
\text { longissimus thoracis. }\end{array}$ & Chen et al., 2021 [106] \\
\hline Mulberry leaf & $4 \%$ & Finishing pig & $\begin{array}{c}\text { increased final BW, ADFI and } \\
\text { ADG, } \\
\text { decreased F/G ratio, improved } \\
\text { slaughter weight, carcass weight, } \\
\text { carcass yield and } \\
\text { meat } \text { a }^{*} \text { value, decreased shear } \\
\text { force, drip loss, MyHCIIx and } \\
\text { MyHCIIb mRNA } \\
\text { levels, and increased MyHCI and } \\
\text { MyHCIla mRNA levels. }\end{array}$ & Chen et al., 2021 [106] \\
\hline $\begin{array}{l}\text { C. militaris spent } \\
\text { mushroom substrate }\end{array}$ & $3,6,9,12 \%$ & Finishing pig & $\begin{array}{l}\text { Increased loin-eye area and } \\
\text { contents of crude protein, inosine } \\
\text { monophosphate and several } \\
\text { amino acids in muscle tissues. } \\
\text { Improved growth performance, } \\
\text { immunoglobulin secretion, and } \\
\text { anti-oxidant capacity, decreased } \\
\text { leukocyte percentage, cholesterol, } \\
\text { and MDA concentrations }\end{array}$ & $\begin{array}{l}\text { Boontiam et al., } 2019 \\
\text { [78] }\end{array}$ \\
\hline $\begin{array}{l}\text { Dietary fiber (Ratio of } \\
\text { insoluble to soluble) }\end{array}$ & $\begin{array}{c}3.89,5.59 \\
9.12,12.81 \%\end{array}$ & Sow & $\begin{array}{l}\text { Improving anti-oxidant and } \\
\text { decreasing inflammatory response } \\
\text { of mothers and their offspring } \\
\text { through modulating the } \\
\text { composition of gut microbiota. } \\
\text { Increased body weight (BW) at }\end{array}$ & Li et al., 2019 [113] \\
\hline $\begin{array}{l}\text { Dietary fiber (Ratio of } \\
\text { insoluble to soluble) }\end{array}$ & $\begin{array}{c}3.89,5.59 \\
9.12,12.81 \%\end{array}$ & Sow & $\begin{array}{l}\text { weaning and piglet BW gain, the } \\
\text { crypt depth of the jejunum in } \\
\text { weaned piglets. }\end{array}$ & Li et al., 2019 [113] \\
\hline Wheat or oat straw & $10 \%$ & Sow & $\begin{array}{l}\text { Wheat straw increased } \\
\text { postprandial IGF-1 and prolactin, } \\
\text { oat straw increased lactation feed } \\
\text { intake and piglet weaning weight. }\end{array}$ & $\begin{array}{l}\text { Agyekum et al., } 2019 \\
\text { [90] }\end{array}$ \\
\hline
\end{tabular}

Note: $b^{*}$ : yellowness; $a^{*}$ : redness.

\subsubsection{Poultry}

Poultry production is developing fast all over the world [22]. Therefore, agro-industry by-products as feedstuffs are in favor of the development of poultry production. The by-product of grape improves gut morphology and intestinal microflora, increases the biodiversity degree of intestinal bacteria and enhances the percentage of unsaturated fatty 
acids $[121,122]$. There is a difference in growth performance when adding high levels of grape seed, but no unifying data of the maximum values exist [123,124]. Zhai et al. (2020) indicated that moringa stem meal, afforded at a rational level (no more than $60 \mathrm{~g} / \mathrm{kg}$ ), could be exploited as a feedstuff for geese in the finisher period [125]. Lombardi et al. (2020) indicated ancient wheat line by-products (consisting 50:50 of triticum aestivum var. spelta and Triticum durum dicoccum L.) could improve feed conversion ratio, reduce the level of cholesterol, triglycerides, ATL and GGT in the blood of laying hens, and increase the amount of butyrate acid in the caecal content of hens. The ancient grain diet could support production performances with positive effects on animal health and on environmental sustainability. [126].

Eggs are ubiquitous in human diets. However, previous studies showed high cholesterol in eggs will impair peoples' health by causing cardiovascular disease [127]. A high number of studies reported that agricultural by-products could reduce cholesterol in eggs $[107,128-130]$. Cayan et al. (2015) reported olive leaf powder improved the final body weight of laying hens, yellowness in yolk color, reduced the concentration of yolk cholesterol [107]. In the study of Gurbuz et al. (2017), sumac (Rhus coriaria L.) seed powder and ginger (Zingiber officinale) root powder could decrease powder yolk and blood cholesterol content and low-density lipoprotein, improved acid composition, ginger root powder. Dehydrated bo-caiuva pulp revealed a potential anti-oxidant capacity and reduced the lipid oxidation in egg yolk [129].

Heat stress is one of the major environmental factors which may reduce growth performance, nutrient availability, immunity and welfare in the poultry industry particularly in tropical and arid regions of the world [131-133]. The addition of by-product feed in the diet for laying hens under heat stress can be beneficial for hen health and can exert positive effects on performance and egg quality $[134,135]$. Tomato pomace diluted the negatively decreased influence of heat stress on the activities of serum enzymes, oxidative status, immune response, and bone ingredients [136]. The above-mentioned studies of by-product feed in poultry are exhibited in Table 4.

Table 4. Applications of agro-industry by-products as feeds in poultry.

\begin{tabular}{|c|c|c|c|c|}
\hline Items & Levels & Monogastric & Main Influences & References \\
\hline Moringa stem meal (MSM) & $20,40,60,80,100 \%$ & Geese & $\begin{array}{l}\text { Dietary MSM levels of no more than } 60 \\
\text { g/kghad no effects on the growth } \\
\text { performance and slaughter } \\
\text { performance, while diets with } 100 \mathrm{~g} \\
\text { MSM/kg increased the F/G and serum } \\
\text { ALT enzyme activity, as well as } \\
\text { decreasing the serum GLU level. }\end{array}$ & Zhai et al., 2019 [125] \\
\hline Tomato pomace & $3,5 \%$ & Broilers & $\begin{array}{l}\text { Attenuated the detrimental effects of } \\
\text { heat stress on the activities of serum } \\
\text { enzymes, oxidative status, immune } \\
\text { response, and bone composition }\end{array}$ & $\begin{array}{l}\text { Hosseini-Vashan et al., } \\
2015 \text { [136] }\end{array}$ \\
\hline Grape pomace & $60 \mathrm{~g} / \mathrm{kg}$ & Broilers & $\begin{array}{c}\text { intestinal microflora and increase the } \\
\text { biodiversity degree of intestinal } \\
\text { bacteria. }\end{array}$ & Viveros et al., 2011 [121] \\
\hline Grape seed extract & $7.2 \mathrm{~g} / \mathrm{kg}$ & Broilers & $\begin{array}{c}\text { Modify the gut morphology and } \\
\text { intestinal microflora and increase the } \\
\text { biodiversity degree of intestinal } \\
\text { bacteria. }\end{array}$ & Viveros et al., 2011 [121] \\
\hline Grape seed & $5 \%$ & Broilers & $\begin{array}{l}\text { Higher percentage of unsaturated fatty } \\
\text { acids due to linoleic acid, more nutty } \\
\text { smell, a more metallic flavour and } \\
\text { more stringiness. }\end{array}$ & Francesch et al., 2015 [122] \\
\hline Olive leaf powder & $1,2,3 \%$ & Laying hens & $\begin{array}{c}\text { Increased final body weight, } \\
\text { yellowness in yolk color, decreased } \\
\text { yolk cholesterol content. }\end{array}$ & Cayan et al., 2015 [107] \\
\hline
\end{tabular}


Table 4. Cont.

\begin{tabular}{|c|c|c|c|c|}
\hline Items & Levels & Monogastric & Main Influences & References \\
\hline $\begin{array}{c}\text { Sumac (Rhus coriaria L.) } \\
\text { seed powder }\end{array}$ & $10,20,30 \%$ & Laying hens & $\begin{array}{c}\text { Reduced yolk/blood cholesterol } \\
\text { concentrations and low-density } \\
\text { lipoprotein, improved acid } \\
\text { composition. }\end{array}$ & $\begin{array}{c}\text { Gurbuz et al., } 2017 \\
\text { [129] }\end{array}$ \\
\hline $\begin{array}{l}\text { Ginger (Zingiber } \\
\text { officinale) root powder }\end{array}$ & $10,20,30 \%$ & Laying hens & $\begin{array}{c}\text { Reduced yolk/blood cholesterol } \\
\text { concentrations and low-density } \\
\text { lipoprotein, improved acid } \\
\text { composition. }\end{array}$ & $\begin{array}{c}\text { Gurbuz et al., } 2017 \\
\text { [129] }\end{array}$ \\
\hline $\begin{array}{l}\text { Dehydrated bocaiuva } \\
\text { pulp }\end{array}$ & $0.1,0.2,0.3,0.4 \%$ & Quail & $\begin{array}{l}\text { Exhibited a potential antioxidant } \\
\text { capacity and reduced the lipid } \\
\text { oxidation in egg yolk. }\end{array}$ & Nunes et al., 2018 [130] \\
\hline $\begin{array}{l}\text { Ancient wheat lines } \\
\text { by-products (consisting } \\
\text { in 50:50 of Triticum } \\
\text { aestivum var. spelta } \\
\text { and Triticum durum } \\
\text { dicoccum L.) }\end{array}$ & $36.3 \%$ & Laying hens & $\begin{array}{l}\text { Improved feed conversion ratio, } \\
\text { decreased egg length and width, } \\
\text { egg weight, shell thickness and } \\
\text { strength, reduced level of } \\
\text { cholesterol, triglycerides, ATL and } \\
\text { GGT in blood, increased the } \\
\text { amount of butyrate acid in the } \\
\text { caecal content of hens. }\end{array}$ & $\begin{array}{l}\text { Lombardi et al., } 2020 \\
\text { [126] }\end{array}$ \\
\hline
\end{tabular}

\subsection{The Use of Agro-Industry By-Products as Feeds in Ruminants}

Ruminants take advantage of high fiber feed because they have substantial microorganism populations in the rumen [137]. Indeed, to produce the equivalent amount of animal protein products (meat, milk or eggs) much less human-edible feed is needed in ruminant systems than in monogastric systems (6 vs. $16 \mathrm{~kg}$ of human-edible feed dry matter (DM) per kilogram of protein products) [5]. The strengths inherent to ruminant animals in the food production chain could be further developed by more diverse and efficient exploitation of side streams and increased exploitation of fibrous feeds not suitable for the nutrition of humans and monogastric livestock. In the past few decades, animal production systems have undergone radical changes that have led to the concentration of large herds in fewer specialized intensive farms, where animals, especially ruminants, are usually kept indoors. Then the feed costs can contribute up to $70 \%$ of total production costs in the ruminant industry due to the lack of grazing on pastures.

Rice straws, wheat straws and other high fiber feeds are commonly used in ruminate [138]. However, energy is crucial to dietary provision for animal production. The data of energy utilizability of untraditional feedstuff formulated are largely unknown. ME and $\mathrm{NE}$ values (dry matter basis) are 6.76 and $3.42 \mathrm{MJ} / \mathrm{kg}$ for rice straw and 6.43 and $3.28 \mathrm{MJ} / \mathrm{kg}$ for wheat straw, respectively [15]. Moreover, the straws treated by fermentation, enzyme, silage, and other methods were proved to exhibit improved quality before application in ruminant feedstuff recently $[139,140]$. The agro-industry by-products like grape pomace or cassava residues used in ruminants are shown in Table 5. Several studies reported that by-products of cassava and grape could improve the production of lambs, dairy ewes and cows [141-150]. Moreover, grape by-products were also able to reduce approximately $20 \%$ of $\mathrm{CH}_{4}$ emissions and $\mathrm{CH}_{4}$ yield of dairy cows [146].

Indeed, there are many other agro-industry by-products of fruits and vegetables like dried citrus pulp and grape pomace that have exhibited a positive relationship in the performance of ruminants [151-154]. It is common to supplement by-product materials to ruminant feeds, however, there is no uniform addition standard. Greenhouse gas emissions have gained world attention because of their effect on the global climate. This comes from the fact that cattle take up more than $11 \%$ of all human-induced greenhouse gases [155]. The nutricine activities which form agro-industry by-products as feeds have been largely investigated in greenhouse gas emissions [154,156-158]. 
Table 5. Applications of agro-industry by-products as feeds in ruminants.

\begin{tabular}{|c|c|c|c|c|}
\hline Items & Levels & Ruminants & Main Influences & References \\
\hline Grape by-product & $0,100,200,300 \mathrm{~g} / \mathrm{kg}$ & Lambs & $\begin{array}{c}\text { Hay replacement by grape by-product at } \\
\text { up to } 300 \mathrm{~g} / \mathrm{kg} \text { in the DM was satisfactory } \\
\text { to weight gain and not impair ADFI and } \\
\text { ADG }\end{array}$ & $\begin{array}{l}\text { Amaral et al., } \\
2019 \text { [141] }\end{array}$ \\
\hline Grape seed and skin & $20 \%$ & Dairy ewes & $\begin{array}{l}\text { Improved milk production, calcium, free } \\
\text { iron and urea content, no influence on milk } \\
\text { fat and protein }\end{array}$ & $\begin{array}{l}\text { Mokni et al., } \\
2016[142]\end{array}$ \\
\hline Grape pomace & $0,5,10,15,20 \%$ & Lamb & $\begin{array}{l}\text { The optimum inclusion of } 12.2 \% \text { grape } \\
\text { pomace improved lamb productivity, } \\
\text { without compromising meat quality }\end{array}$ & $\begin{array}{l}\text { Chikwanha et al., } \\
2019 \text { [143] }\end{array}$ \\
\hline Grape pomace & $5,10 \%$ & Suckling lambs & $\begin{array}{l}\text { No negative effects on meat quality besides } \\
\text { the water holding capacity improved. } \\
\text { Ruminal microbial N decreased and }\end{array}$ & $\begin{array}{c}\text { Gómez-Cortés et al., } \\
2018 \text { [144] }\end{array}$ \\
\hline $\begin{array}{l}\text { Distillers' grape } \\
\text { residue }\end{array}$ & $\begin{array}{l}3.85,7.70,11.55 \\
\quad 15.41 \%\end{array}$ & Lamb & $\begin{array}{l}\text { un-degradable protein and N retention } \\
\text { increased. Suggested not exceeding } 10 \% \text { of } \\
\text { the diet }\end{array}$ & $\begin{array}{l}\text { Gao et al., } \\
2019 \text { [145] }\end{array}$ \\
\hline Grape marc & $5 \mathrm{~kg} /$ day & Dairy cow & $\begin{array}{c}\text { Decreases of approximately } 20 \% \text { in } \mathrm{CH}_{4} \\
\text { emissions and } \mathrm{CH}_{4} \text { yield }\end{array}$ & $\begin{array}{l}\text { Moate et al., } \\
2014 \text { [146] }\end{array}$ \\
\hline Grape pomace & $15 \%$ & Dairy cow & $\begin{array}{l}\text { No negative influence on blood constituent } \\
\text { metabolism and the fat, protein and caseins } \\
\text { in milk, but increase other components. }\end{array}$ & $\begin{array}{l}\text { Chedea et al., } \\
2016 \text { [147] }\end{array}$ \\
\hline Grape pomace & $10 \%$ & Cattle & Reflects antioxidant activity & $\begin{array}{l}\text { Iannaccone et al., } \\
\quad 2018 \text { [148] }\end{array}$ \\
\hline Cassava residue & $5,10,20 \%$ & Lambs (21 kg) & $\begin{array}{l}\text { Improve growth performance, damage } \\
\text { antioxidant capacity and kidney function, } \\
\text { suggested less than } 20 \%\end{array}$ & $\begin{array}{l}\text { Lv et al., } \\
2017[29]\end{array}$ \\
\hline $\begin{array}{c}\text { Cassava } \\
\text { residue(Liquid) }\end{array}$ & $\begin{array}{l}\text { Replacement of } 25,50, \\
75 \% \text { corn }\end{array}$ & Lambs $(19.5 \mathrm{~kg})$ & $\begin{array}{c}\text { The maximum average daily gain }(174 \\
\text { g/day) was estimated with a } 22.4 \% \\
\text { replacement level }\end{array}$ & $\begin{array}{l}\text { Dos Santos et al., } \\
\quad 2015 \text { [149] }\end{array}$ \\
\hline $\begin{array}{l}\text { Cassava chips or } \\
\text { fermented cassava } \\
\text { starch residue }\end{array}$ & $100 \%$ & $\begin{array}{l}\text { Thai native-Lowline } \\
\text { Angus crossbred } \\
\text { steers }\end{array}$ & $\begin{array}{l}\text { replacement of cassava chip in the } \\
\text { concentrate with FCSR decreased feed } \\
\text { digestibility; not impact negatively on } \\
\text { growth performance and carcass traits }\end{array}$ & $\begin{array}{l}\text { Pilajun et al., } \\
2016[150]\end{array}$ \\
\hline $\begin{array}{l}\text { Fruit and vegetable } \\
\text { waste }\end{array}$ & $6,8,12,18 \%$ & $\begin{array}{l}\text { Lactating Holstein } \\
\text { cows }\end{array}$ & $\begin{array}{l}\text { No negative influence on ADFI and milk } \\
\text { yield but improve milk quality. }\end{array}$ & $\begin{array}{l}\text { Angulo et al., } \\
2012 \text { [151] }\end{array}$ \\
\hline $\begin{array}{l}\text { Fruit by-products } \\
(\text { dried citrus } \\
\text { pulp(GDP), Grape } \\
\text { pomace(DGP) })\end{array}$ & $150 \mathrm{~g} / \mathrm{kg}$ & Angus steer & $\begin{array}{l}\text { GP is a better fiber source than DCP to } \\
\text { enhance growth performance, carcass } \\
\text { attributes and economic viability }\end{array}$ & $\begin{array}{l}\text { Tayengwa et al., } \\
2020 \text { [152] }\end{array}$ \\
\hline $\begin{array}{l}\text { DDGS, dried citrus } \\
\text { pulp (DCP), } \\
\text { exhausted olive cake } \\
\text { (EOC) }\end{array}$ & $18,18,8 \%$ respectively & Lamb & $\begin{array}{l}44 \% \text { of feed ingredients in the concentrate } \\
\text { replaced without negative growth } \\
\text { performance and animal health }\end{array}$ & $\begin{array}{l}\text { De Evan et al., } \\
2020 \text { [153] }\end{array}$ \\
\hline $\begin{array}{l}\text { Grocery by-product } \\
\text { feed }\end{array}$ & $18,36,54 \%$ & Cattle & $\begin{array}{c}\text { Increase DM intake and energy and TDN } \\
\text { digestibility }\end{array}$ & $\begin{array}{l}\text { Froetschel et al., } \\
\quad 2014 \text { [154] }\end{array}$ \\
\hline
\end{tabular}

DDGS: corn distiller's dried grains with solubles; DCP: dried citrus pulp; EOC: exhausted olive cake.

\section{Developmental Strategies for Agro-Industry By-Products}

The agro-industry by-products have great potential for animal feedings. However, the utilization has different limits due to the large variability in their chemical compositions and physical status, their seasonal production, short shelf-life, high moisture, and fat levels. To increase the by-products' shelf-life, some precautions could be adopted, such as treating by-products rich in water with a hygroscopic substance (e.g., lime) or adding anti-oxidants to the by-products rich in fats. More attention should be paid to the pesticide residue in fruit and vegetable by-products that impair animal health [159]. Agro-industry by-product as feedstuffs should be promoted because of heavy demand for intensification in the future. A change from the traditional to more intensive systems of production is likely to result from different factors such as scarcity of grazing land, need for more control over animals, and higher returns from the stall-feeding system. The quantity of usage of agro-industry by-products relies on the availability of the resources and the technical facility utilized for its preparation, reservation, and improvement. Many countries are in the direction of making the most of all products which are adequate for animal feed. Moreover, the appropriate 
methods of collection, transportation, and processing contribute to decrease the expenses and further the nutritive value. The following tactics are recognized to be significant to improve productivity from the animal resources through more efficient utilization of agro-industry by-products [58]:

1. More intensive use in stall-feeding systems.

2. Development of complete rations.

3. Strategic supplementation.

4. Wider use of by-products.

5. Nutrient enrichment of by-products.

\section{Conclusions}

Most agro-industry by-products including stalks and residues are rich in nutrients as raw materials that are particularly well suited to serve as the base of animal feeds. Stalks are high in dietary fiber but low in protein and minerals while residues are high in protein and other nutrients. Unfortunately, agro-industry by-products also have many shortcomings such as the presence of anti-nutritional ingredients. However, modern processing methods, new sorts, and appropriate developmental strategies are expanding the applications of agro-industry by-products as animal feeding including pigs, poultry and ruminants. That said, the processing methods and developmental strategies still need further improvement. The utilization of agro-industry by-products for animal production will become a sound foundation for sustained development technology and the management of animal farming.

Author Contributions: Investigation, K.Y.; writing-original draft preparation, K.Y., Y.Q., Q.Y.; writing-review and editing, X.T., G.C. and H.L.; project administration, R.F.; funding acquisition, R.F. All authors have read and agreed to the published version of the manuscript.

Funding: We greatly appreciate of the funding support of the Division of Animal Nutrition and Feed Science, Hunan Herbevores Industry Technological System, and National Key R\&D Program of China (2018YFD0500605, 2018YFD0501403).

Data Availability Statement: The data presented in this study are available on request from the authors.

Conflicts of Interest: The authors declare no conflict of interest.

\section{References}

1. World Development Report. Agriculture for Development; World Ban: Washington, DC, USA, 2008.

2. FAO. The State of Food and Agriculture 2019. In Moving Forward on Food Loss and Waste Reduction; FAO: Rome, Italy, 2019.

3. FAO. The State of Food and Agriculture 2011. In Moving Forward on Food Loss and Waste Reduction; FAO: Rome, Italy, 2011.

4. FAOSTAT. Food and Agriculture Data; FAO: Rome, Italy, 2016; Available online: http:/ / www.fao.org/statistics/en/ (accessed on 12 May 2020).

5. Mottet, A.; Haan, C.; Falcucci, A.; Tempio, G.; Opio, C.; Gerber, P. Livestock: On our plates oreating at our table? A new analysis of the feed/food debate. Glob. Food Secur. 2017, 14, 1-8. [CrossRef]

6. Kim, S.W.; Less, J.F.; Wang, L.; Yan, T.; Kiron, V.; Kaushik, S.J.; Lei, X.G. Meeting Global Feed Protein Demand: Challenge, Opportunity, and Strategy. Annu. Rev. Anim. Biosci. 2019, 7, 221-243. [CrossRef] [PubMed]

7. Abd El-Hack, M.E.; Samak, D.H.; Noreldin, A.E.; Arif, M.; Yaqoob, H.S.; Swelum, A.A. Towards saving freshwater: Halophytes as unconventional feedstuffs in livestock feed: A review. Environ. Sci. Pollut. 2018, 25, 14397-14406. [CrossRef] [PubMed]

8. Zhang, X.M.; Wang, M.; Yu, Q.; Ma, Z.Y.; Beauchemin, K.A.; Wang, R.; Ren, J.N.; Lukuyu, B.A.; Tan, Z.L. Liquid hot water treatment of rice straw enhances anaerobic degradation and inhibits methane production during in vitro ruminal fermentation. $J$. Dairy Sci. 2020, 103, 4252-4261. [CrossRef]

9. Villanueva, Z.; Ibarra, M.A.; Briones, F.; Escamilla, O.S. Productive performance of hair lambs fed fresh orange (Citrus sinensis) residues substituting sorghum (Sorghum vulgare) grains. Cuban J. Agric. Sci. 2013, 47, 27-31.

10. Fernandes, P.A.R.; Bourvellec, L.C.; Renard, C.M.G.C.; Nunes, F.M.; Bastos, R.; Coelho, E.; Wessel, D.F.; Coimbra, M.A.; Cardoso, S.M. Revisiting the chemistry of apple pomace polyphenols. Food Chem. 2019, 294, 9-18. [CrossRef] [PubMed]

11. Georganas, A.; Giamouri, E.; Pappas, A.C.; Papadomichelakis, G.; Galliou, F.; Manios, T.; Tsiplakou, E.; Fegeros, K.; Zervas, G. Bioactive Compounds in Food Waste: A Review on the Transformation of Food Waste to Animal Feed. Foods $2020,9,291$. [CrossRef]

12. Lu, D.X. Feed nutricines: A research area that is worth to examine closely. Feed Ind. 2020, 41, 1-5. (In Chinese) 
13. Xue, J.J.; Li, S.Y.; Fang, R.J. Research progress of nutrition regulation technology for soybean meal reduction in livestock and poultry diets. Chin. J. Anim. Nutr. 2019, 31, 3438-3447. (In Chinese)

14. Wang, B.; Mao, S.Y.; Yang, H.J.; Wu, Y.M.; Wang, J.K.; Li, S.L.; Shen, Z.M.; Liu, J.X. Effects of alfalfa and cereal straw as a forage source on nutrient digestibility and lactation performance in lactating dairy cows. J. Dairy Sci. 2014, 97, 7706-7715. [CrossRef] [PubMed]

15. Wei, M.; Cui, Z.; Li, J.; Yan, P. Estimation of metabolisable energy and net energy of rice straw and wheat straw for beef cattle by indirect calorimetry. Arch Anim. Nutr. 2018, 72, 275-289. [CrossRef] [PubMed]

16. Bampidis, V.A.; Christodoulou, V. Chickpeas (Cicer arietinum L.) in animal nutrition: A review. Anim. Feed Sci. Technol. 2011, 168, 1-20. [CrossRef]

17. Zhang, Z.J.; Guo, T.J.; Zhao, J.; Sang, D.J.; Shi, Y.; Cui, J.W. Effects of steam explosion and fermentation after steam explosion on nutrient value of cotton stalk. Chin. J. Anim. Nutr. 2018, 30, 3720-3725. (In Chinese)

18. Zhou, J.J.; Wei, W.; Qin, A.Q.; Chen, B.J. Effects of moisture and additives on the quality of pepper straw silage. Acta Pratacultrae Sin. 2016, 25, 231-239.

19. Shen, R.R.; Sun, X.Y.; Liu, B.; Li, Y.Q.; Gao, Y.X.; Li, J.G.; Cao, Y.F.; Li, Q.F. Effects of Different Compound Microorganism Preparations on Fermentation Quality, Nutritional Components and Rumen Degradation Rate of Mixed Silage of Potato Pulp and Soybean Straw. Chin. J. Anim. Nutr. 2019, 31, 3319-3329.

20. Lan, G.S.; Wang, F.B.; Zhang, Z.A.; Li, F.; Li, F.D. Using Cornell Net Carbohydrate-Protein System and Cluster Analysis Technique to Evaluate the Nutritional Value of Rape Straw. Chin. J. Anim. Nutr. 2019, 31, 1877-1886. (In Chinese)

21. Yuan, J.; Wang, X.J. In vitro study on the effect of supplementing an alfalfa diet with straw or shells fennel, sunflower, and cotton, and their associative effects. Acta Prataculturae Sin. 2018, 27, 163-172. (In Chinese)

22. National Research Council. Critical Role of Animal Science Research in Food Security and Sustainability; The National Academies Press: Washington, DC, USA, 2015.

23. Xiong, M.L.; Wu, X.J.; Zhu, X.F.; Zhang, W.J. Effects of Apple Pomace on Growth Performance, Organ Indexes and Serum Biochemical Indexes of Guanzhong Dairy Goats. Chin. J. Anim. Nutr. 2020, 32, 2683-2689. (In Chinese)

24. Pluschke, A.M.; Williams, B.A.; Zhang, D.; Gidley, M.J. Dietary pectin and mango pulp effects on small intestinal enzyme activity levels and macronutrient digestion in grower pigs. Food Funct. 2018, 9, 991-999. [CrossRef] [PubMed]

25. Mínguez, C.; Calvo, A. Effect of supplementation with fresh orange pulp (Citrus sinensis) on mortality, growth performance, slaughter traits and sensory characteristics in meat guinea pigs. Meat Sci. 2018, 145, 51-54. [CrossRef] [PubMed]

26. Correddu, F.; Nudda, A.; Battacone, G.; Boe, R.; Francesconi, A.H.D.; Pulina, G. Effects of grape seed supplementation, alone or associated with linseed, on ruminal metabolism in Sarda dairy sheep. Anim. Feed Sci. Technol. 2015, 199, 61-72. [CrossRef]

27. Ishida, K.; Kishi, Y.; Oishi, K.; Hirooka, H.; Kumagai, H. Effects of feeding polyphenol-rich winery wastes on digestibility, nitrogen utilization, ruminal fermentation, antioxidant status and oxidative stress in wethers. Anim. Sci. J. 2015, 86, 260-269. [CrossRef] [PubMed]

28. Abbeddou, S.; Rischkowsky, B.; Richter, E.K.; Hess, H.D.; Kreuzer, M. Modification of milk fatty acid composition by feeding forages and agro-industrial by-products from dry areas to Awassi sheep. J. Dairy Sci. 2011, 94, 4657-4668. [CrossRef] [PubMed]

29. Lv, X.K.; Wang, J.; Wang, S.Q.; Cui, K.; Diao, Q.Y.; Zhang, N.F. Effects of dietary cassava residue supplementation on growth performance, serum indexes and rumen fermentation indexes of growing lambs. Chin. J. Anim. Nutr. 2017, 29, 3666-3675. (In Chinese)

30. Ghasemi, S.; Naserian, A.A.; Valizadeh, R.; Tahmasebi, A.M.; Vakili, A.R.; Behgar, M.; Ghovvati, S. Inclusion of pistachio hulls as a replacement for alfalfa hay in the diet of sheep causes a shift in the rumen cellulolytic bacterial population. Small Rumin. Res. 2012, 104, 94-98. [CrossRef]

31. Valenti, B.; Luciano, G.; Morbidini, L.; Rossetti, U.; Codini, M.; Avondo, M.; Priolo, A.; Bella, M.; Natalello, A.; Pauselli, M. Dietary pomegranate pulp: Effect on ewe milk quality during late lactation. Animals 2019, 9, 283. [CrossRef]

32. Fegeros, K.; Zervas, G.; Stamouli, S.; Apostolaki, E. Nutritive Value of Dried Citrus Pulp and Its Effect on milk yield and milk composition of lactating ewes. J. Dairy Sci. 1995, 78, 1116-1121. [CrossRef]

33. Castrica, M.; Rebucci, R.; Giromini, C.; Tretola, M.; Cattaneo, D.; Baldi, A. Total phenolic content and antioxidant capacity of agri-food waste and by-products. Ital. J. Anim. Sci. 2019, 18, 336-341. [CrossRef]

34. Campbell, T.W.; Bartley, E.E.; Bechtle, R.M.; Dayton, A.D. Coffee Grounds. I. Effects of Coffee Grounds on Ration Digestibility and Diuresis in Cattle, on In Vitro Rumen Fermentation, and on Rat Growth. J. Dairy Sci. 1976, 59, 1452-1460. [CrossRef]

35. Valdez-Arjona, L.P.; Ramírez-Mella, M. Pumpkin waste as livestock feed: Impact on nutrition and animal health and on quality of meat, milk, and egg. Animals 2019, 9, 769. [CrossRef]

36. Das, N.G.; Huque, K.S.; Amanullah, S.M.; Harinder, P.S.M. Feeding of processed vegetable wastes to bulls and its potential environmental benefit. Anim. Nutr. 2018, 5, 87-94. [CrossRef] [PubMed]

37. Zhang, X.; Huang, X.; Li, C.; Wang, X.R.; Jiang, G.T.; Wu, D.Q.; Dai, Q.Z. Effects of compound enzyme preparation on nutrient utilization rate and metabolize energy of several residue type ingredients. Chin. J. Anim. Nutr. 2017, 29, 4433-4439. (In Chinese)

38. Li, J.T.; Yang, F.T.; Wang, S.K.; Zhang, E.P. Screening of Cellulose-Degradation Strains and Condition Optimization of Mixed Strains Fermentation of Pleurotus eryngii Spent Mushroom Substrate. Chin. J. Anim. Nutr. 2019, 31, 4802-4816. (In Chinese) 
39. Wegi, T.; Tolera, A.; Wamatu, J.; Animut, G.; Rischkowsky, B. Effects of feeding different varieties of faba bean (Vicia faba L.) straws with concentrate supplement on feed intake, digestibility, body weight gain and carcass characteristics of Arsi-Bale sheep. Asian-Australas. J. Anim. Sci. 2018, 31, 1221-1229. [CrossRef] [PubMed]

40. Zhang, Y.F. Nutritional value assessment and associative effect of phragmites hay. Master's Thesis, Hebei Agricultural University, Baoding, China, 2019. (In Chinese).

41. Cai, M. Study on evaluation of safety and feeding value of mulberry(Morus alba L.) leaves as animal feed. Ph.D. Thesis, Lanzhou University, Lanzhou, China, 2019. (In Chinese).

42. Hossain, M.E.; Karim, M.H.; Ahmed, M.I.; Sultana, S.A. Hilly grasses and leaves: A promising unconventional feed resource for livestock. Online J. Anim. Feed Res. 2016, 6, 1-7.

43. Hao, Y.Y.; He, Y.Q.; Liu, G.K.; Lu, J.Y.; Sun, X.G.; Ma, G.L.; Zhao, H.; Wang, Y.J.; Li, S.L. Effects of different cutting heights on yield, nutritional composition, silage fermentation quality and in vitro fermentation of hybrid paper mulberry. Chin. J. Anim. Nutr. 2020, 35, 2387-23960. (In Chinese)

44. Halmemies-Beauchet-Filleau, A.; Rinne, M.; Lamminen, M.; Mapato, C.; Ampapon, T.; Wanapat, M.; Vanhatalo, A. Review: Alternative and novel feeds for ruminants: Nutritive value, product quality and environmental aspects. Animals 2018, 12, s295-s309. [CrossRef] [PubMed]

45. Gowda, N.K.; Ramana, J.V.; Prasad, C.S.; Singh, K. Micronutrient content of certain tropical conventional and unconventional feed resources of Southern India. Trop. Anim. Health Prod. 2004, 36, 77-94. [CrossRef] [PubMed]

46. Greenwood, R.H.; Morrill, J.L.; Titgemeyer, E.C.; Kennedy, G.A. A new method of measuring diet abrasion and its effect on the development of the forestomach. J. Dairy Sci. 1997, 80, 2534-2541. [CrossRef]

47. Sood, S.; Joshi, D.C.; Chandra, A.K.; Kumar, A. Phenomics and genomics of finger millet: Current status and future prospects. Planta 2019, 250, 731-751. [CrossRef] [PubMed]

48. Chen, X.; Mi, H.; Cui, K.; Zhou, R.; Tian, S.; Zhang, L. Effects of Diets Containing Finger Millet Straw and Corn Straw on Growth Performance, Plasma Metabolites, Immune Capacity, and Carcass Traits in Fattening Lambs. Animals 2020, 10, 1285. [CrossRef] [PubMed]

49. Kamruzzaman, M.; Liang, X.; Sekiguchi, N.; Sano, H. Effect of feeding garlic leaf on microbial nitrogen supply, kinetics of plasma phenylalanine, tyrosine and protein synthesis in sheep. Anim. Sci. J. 2014, 85, 542-548. [CrossRef]

50. Lee, Y.H.; Kim, Y.I.; Oh, Y.K.; Ahmadi, F.; Kwak, W.S. Yield survey and nutritional evaluation of garlic stalk for ruminant feed. J. Anim. Sci. Technol. 2017, 59, 22. [CrossRef] [PubMed]

51. Di, M.G.; Capello, K.; Scollo, A.; Gottardo, F.; Stefani, A.L.; Rampin, F.; Schiavon, E.; Marangon, S.; Bonfanti, L. Continuous straw provision reduces prevalence of oesophago-gastric ulcer in pigs slaughtered at $170 \mathrm{~kg}$ (heavy pigs). Res. Vet. Sci. 2013, 95, 1271-1273.

52. Jensen, M.B.; Herskin, M.S.; Canibe, N.; Forkman, B.; Pedersen, L.J. Effect of straw amount on feed intake and weight gain in growing pigs housed in pens with partly slatted floor. Animals 2019, 23, 1-8. [CrossRef]

53. Knudsen, K.E.B. Carbohydrate and lignin contents of plant materials used in animal feeding. Anim. Feed Sci. Tech. 1997, 67, 330-338. [CrossRef]

54. Wang, Z.; Zhao, J.; Xu, J.; Jia, M.; Li, H.; Wang, S. Influence of straw burning on urban air pollutant concentrations in Northeast China. Int. J. Environ. Res. Public Health 2019, 16, 1379. [CrossRef]

55. Selaledi, L.; Mbajiorgu, C.A.; Mabelebele, M. The use of yellow mealworm (T. molitor) as alternative source of protein in poultry diets: A review. Trop. Anim. Health Prod. 2020, 52, 7-16. [CrossRef] [PubMed]

56. Konkol, D.; Szmigiel, I.; Domżał-Kędzia, M.; Kułażyński, M.; Krasowska, A.; Opaliński, S.; Korczyński, M.; Łukaszewicz, M. Biotransformation of rapeseed meal leading to production of polymers, biosurfactants, and fodder. Bioorg. Chem. 2019, $93,102865$. [CrossRef]

57. Yu, J.; Wang, Z.Y.; Yang, H.M.; Xu, L.; Wan, X.L. Effects of cottonseed meal on growth performance, small intestinal morphology, digestive enzyme activities, and serum biochemical parameters of geese. Poult. Sci. 2019, 98, 2066-2071. [CrossRef]

58. Ajila, C.M.; Brar, S.K.; Verma, M.; Tyagi, R.D.; Godbout, S.; Valéro, J.R. Bio-processing of agro-by-products to animal feed. Crit Rev. Biotechnol. 2012, 32, 382-400. [CrossRef]

59. Tańska, M.; Roszkowska, B.; Czaplicki, S.; Borowska, E.J.; Bojarska, J.; Dabrowska, A. Effect of Fruit Pomace Addition on Shortbread Cookies to Improve Their Physical and Nutritional Values. Plant Foods Hum. Nutr. 2016, 71, 307-313. [CrossRef]

60. Vithana, M.D.; Singh, Z.; Johnson, S.K. Regulation of the levels of health promoting compounds: Lupeol, mangiferin and phenolic acids in the pulp and peel of mango fruit: A review. J. Sci. Food Agric. 2019, 99, 3740-3751. [CrossRef] [PubMed]

61. Czech, A.; Zarycka, E.; Yanovych, D.; Zasadna, Z.; Grzegorczyk, I.; Kłys, S. Mineral Content of the Pulp and Peel of Various Citrus Fruit Cultivars. Biol. Trace Elem. Res. 2020, 193, 555-563. [CrossRef]

62. Fuller, S.; Beck, E.; Salman, H.; Tapsell, L. New Horizons for the Study of Dietary Fiber and Health: A Review. Plant Foods Hum. Nutr. 2016, 71, 1-12. [CrossRef] [PubMed]

63. Fraga, C.G.; Croft, K.D.; Kennedy, D.O.; Tomás-Barberán, F.A. The effects of polyphenols and other bioactives on human health. Food Funct. 2019, 10, 514-528. [CrossRef] [PubMed]

64. Joseph, S.V.; Edirisinghe, I.; Burton-Freeman, B.M. Fruit Polyphenols: A Review of Anti-inflammatory Effects in Humans. Crit Rev. Food Sci. Nutr. 2016, 56, 419-444. [CrossRef] 
65. Moallem, U. Invited review: Roles of dietary n-3 fatty acids in performance, milk fat composition, and reproductive and immune systems in dairy cattle. J. Dairy Sci. 2018, 101, 8641-8661. [CrossRef] [PubMed]

66. Liu, H.; Yu, Q.F.; Fang, C.K.; Chen, S.J.; Tang, X.P.; Ajuwon, K.M.; Fang, R.J. Effect of selenium source and level on performance, egg quality, egg selenium content, and serum biochemical parameters in laying hens. Foods 2020, 9, 68. [CrossRef]

67. Khan, S.A. Inclusion of pyridoxine to flaxseed cake in poultry feed improves productivity of omega-3 enriched eggs. Bioinformation 2019, 15, 333-341. [CrossRef]

68. Lomascolo, A.; Uzan-Boukhris, E.; Sigoillot, J.C.; Fine, F. Rapeseed and sunflower meal: A review on biotechnology status and challenges. Appl. Microbiol. Biotechnol. 2012, 95, 1105-1114. [CrossRef]

69. Li, P.; Wu, G. Composition of amino acids and related nitrogenous nutrients in feedstuffs for animal diets. Amino Acids. 2020, 52, 523-542. [CrossRef] [PubMed]

70. Wu, G. Amino Acids: Biochemistry and Nutrition; CRC Press: Boca Raton, FL, USA, 2013.

71. Kerr, B.J.; Jha, R.; Urriola, P.E.; Shurson, G.C. Nutrient composition, digestible and metabolizable energy content, and prediction of energy for animal protein by-products in finishing pig diets. J. Anim. Sci. 2017, 95, 2614-2626.

72. Miles, R.D.; Jacob, J.P. Fishmeal: Understanding why this Feed Ingredient is so Valuable in Poultry Diets. Anim. Sci. 2011, PS30, 1-3. Available online: http:/ / ufdc.ufl.edu/IR00004264/00001 (accessed on 22 February 2021).

73. Apple, J.K.; Boger, C.B.; Brown, D.C.; Maxwell, C.V.; Friesen, K.G.; Roberts, W.J.; Johnson, Z.B. Effect of feather meal on live animal performance and carcass quality and composition of growing-finishing swine. J. Anim. Sci. 2003, 81, 172-181. [CrossRef] [PubMed]

74. Anderson, R.M.; Donnelly, C.A.; Ferguson, N.M.; Woolhouse, M.E.; Watt, C.J.; Udy, H.J.; MaWhinney, S.; Dunstan SP Southwood, T.R.; Wilesmith, J.W.; Ryan, J.B.; et al. Transmission dynamics and epidemiology of BSE in British cattle. Nature 1996, 382, 779-788. [CrossRef] [PubMed]

75. Hahn, H. Animal meal: Production and determination in feedstuffs and the origin of bovine spongiform encephalopathy. Naturwissenschaften 1999, 86, 62-70. [CrossRef]

76. Jordan, S.N.; Mullen, G.J.; Murphy, M.C. Composition variability of spent mushroom compost in Ireland. Bioresour. Technol. 2008, 99, 411-418. [CrossRef]

77. Phan, C.W.; Sabaratnam, V. Potential uses of spent mushroom substrate and its associated lignocellulosic enzymes. Appl. Microbiol. Biotechnol. 2012, 96, 863-873. [CrossRef]

78. Boontiam, W.; Wachirapakorn, C.; Wattanachai, S. Growth performance and hematological changes in growing pigs treated with Cordyceps militaris spent mushroom substrate. Vet. World. 2019, 13, 768-773. [CrossRef] [PubMed]

79. Singh, A.D.; Vikineswary, S.; Abdullah, N.; Sekaran, M. Enzymes from spent mushroom substrate of Pleurotus sajor-caju for the decolourisation and detoxification of textile dyes. World J. Microbiol. Biotechnol. 2011, 27, 535-545. [CrossRef]

80. Vastolo, A.; Calabró, S.; Liotta, L.; Musco, N.; Rosa, A.R.D.; Cutrignelli, M.I.; Chiofalo, B. In Vitro fermentation and chemical characteristics of mediterranean by-products for swine nutrition. Animals 2019, 9, 556. [CrossRef]

81. He, S.; Simpson, B.K.; Sun, H.; Ngadi, M.O.; Huang, T. Phaseolus vulgaris lectins: A systematic review of characteristics and health implications. Crit. Rev. Food Sci. 2015, 58, 70-83. [CrossRef]

82. Huang, Q.Q.; Liu, X.L.; Zhao, G.Q.; Hu, T.M.; Wang, Y.X. Potential and challenges of tannins as an alternative to in-feed antibiotics for farm animal production. Anim. Nutr. 2018, 4, 137-150. [CrossRef]

83. Olukomaiya, O.O.; diamo, O.Q.; Hrishanthi Fernando, W.; Mereddy, R.; Li, X.; Sultanbawa, Y. Effect of solid-state fermentation on proximate composition, anti-nutritional factor, microbiological and functional properties of lupin flour. Food Chem. 2020, 315, 126238. [CrossRef]

84. Khempaka, S.; Thongkratok, R.; Okrathok, S.; Molee, W. An evaluation of cassava pulp feedstuff fermented with A. oryzae, on growth performance, nutrient digestibility and carcass quality of broilers. J. Poult. Sci. 2014, 51, 71-79. [CrossRef]

85. Sugiharto, S.; Yudiarti, T.; Isroli, I. Performances and haematological profile of broilers fed fermented dried cassava (Manihotesculenta Crantz). Trop. Anim. Health Prod. 2016, 48, 1337-1341. [CrossRef] [PubMed]

86. Beauchemin, K.A.; Rode, L.M. Use of feed enzymes in ruminant nutrition. In Animal Science Research and Development-Meeting Future Challenges; Minister of Supply and Services: Ottawa, ON, Canada, 1996; pp. 103-130.

87. Zheng, J.; Rehmann, L. Extrusion pretreatment of lignocellulosic biomass: A review. Int. J. Mol. Sci. 2014, 15, 18967-18984. [CrossRef]

88. Akobi, C.; Yeo, H.; Hafez, H.; Nakhla, G. Single-stage and two-stage anaerobic digestion of extruded lignocellulosic biomass. Appl. Energ. 2016, 184, 548-559. [CrossRef]

89. Chen, Y.; Zhao, Z.; Zou, H.; Yang, H.; Sun, T.; Li, M.; Chai, H.; Li, L.; Ai, H.; Shi, D.; et al. Digestive performance of sludge with different crop straws in mesophilic anaerobic digestion. Bioresour. Technol. 2019, 289, 121595. [CrossRef] [PubMed]

90. Agyekum, A.K.; Columbus, D.A.; Farmer, C.; Beaulieu, A.D. Effects of supplementing processed straw during late gestation on sow physiology, lactation feed intake, and offspring body weight and carcass quality1. J. Anim. Sci. 2019, 97, 3958-3971. [CrossRef]

91. Ravindran, V.; Son, J.H. Feed enzyme technology: Present status and future developments. Recent Pat Food Nutr. Agric. 2011, 3 , 102-109. [PubMed]

92. Myers, S.J.; Cheetham, P.S.J.; Banister, N.E. Method of Treating Plant Materials with Hydrolytic Enzymes. International Patent WO1996039859, 19 December 1996. 
93. Niba, A.T.; Beal, J.D.; Kudi, A.C.; Brooks, P.H. Potential of bacterial fermentation as a biosafe method of improving feeds for pigs and poultry. Afr. J. Biotechnol. 2009, 8, 1758-1767.

94. Couto, S.R.; Sanroman, M.A. Application of solid-state fermentation to food industry-a review. J. Food Eng. 2006, 76, 291-302. [CrossRef]

95. Supriyati, T.H.; Susanti, T.; Susana, I.W.R. Nutritional value of rice bran fermented by Bacillus amyloliquefaciens and humic substances and its utilization as a feed ingredient for broiler chickens. Asian Australas J. Anim. Sci. 2015, 28, 231-238. [CrossRef]

96. Gupta, S.; Lee, J.J.L.; Chen, W.N. Analysis of Improved Nutritional Composition of Potential Functional Food (Okara) after Probiotic Solid-State Fermentation. J. Agric Food Chem. 2018, 66, 5373-5381. [CrossRef]

97. Wang, Z.; Zhang, Z.Q.; Jiang, N.; Zhang, A.Z. Mix fermentation of corn straw by trichoderma koningiopsis, phanerochaete chrysopoium and saccharomyces cerevisiae to increase crude protein content of corn straw. Chin. J. Anim. Nutr. 2020, 32, 1284-1292. (In Chinese)

98. Wu, L.P.; Jiang, N.; Zhang, A.Z. Screening experiment of fermented corn stalk with fungi and enzyme mixed preparation. Chin. J. Anim. Nutr. 2020, 32, 1-7. (In Chinese)

99. Zhu, F.; Su, D.; Ran, L.; Fan, C.Y.; Zhang, Z.J.; Liu, Z.Q.; Wan, X.C.; Cheng, J.B. Nutritional improvement of tea residue by solid-state fermentation with Aspergillus niger. Chin. J. Anim. Nutr. 2018, 30, 4269-4278. (In Chinese)

100. McDonald, P.; Henderson, A.R.; Heron, S.J.E. The Biochemistry of Silage; Chalcombe Publications: Marlow, UK, 1991.

101. Anantasook, N.; Wanapat, M.; Cherdthong, A.; Gunun, P. Effect of tannins and saponins in Samanea saman on rumen environment, milk yield and milk composition in lactating dairy cows. J. Anim. Physiol Anim. Nutr. 2015, 99, 335-344. [CrossRef]

102. Koenig, K.M.; Beauchemin, K.A.; Mcginn, S.M. Feeding condensed tannins to mitigate ammonia emissions from beef feedlot cattle fed high-protein finishing diets containing distillers grains. J. Anim. Sci. 2018, 96, 4414-4430. [CrossRef] [PubMed]

103. Retes, P.L.; Clemente, A.H.S.; Neves, D.G.; Espósito, M.; Makiyama, L.; Alvarenga, R.R.; Pereira, L.J.; Zangeronimo, M.G. In ovo feeding of carbohydrates for broilers-a systematic review. J. Anim. Physiol Anim. Nutr. 2017, 102, 361-369. [CrossRef]

104. Kurekci, C.; Al Jassim, R.; Hassan, E.; Bishop-Hurley, S.L.; Padmanabha, J.; McSweeney, C.S. Effects of feeding plant-derived agents on the colonization of Campylobacter jejuni in broiler chickens. Poult. Sci. 2014, 93, 2337-2346. [CrossRef] [PubMed]

105. Abd El-Hack, M.E.; Samak, D.H.; Noreldin, A.E.; El-Naggar, K.; Abdo, M. Probiotics and plant-derived compounds as eco-friendly agents to inhibit microbial toxins in poultry feed: A comprehensive review. Environ. Sci. Pollut. Res. Int. 2018, 25, 31971-31986. [CrossRef]

106. Chen, Z.; Xie, Y.; Luo, J.; Chen, T.; Xi, Q.; Zhang, Y.; Sun, J. Dietary supplementation with Moringa oleifera and mulberry leaf affects pork quality from finishing pigs. J. Anim. Physiol. Anim. Nutr. 2021, 105, 72-79. [CrossRef]

107. Cayan, H.; Erener, G. Effect of Olive Leaf (Olea europaea) Powder on Laying Hens Performance, Egg Quality and Egg Yolk Cholesterol Levels. Asian-Australas J. Anim. Sci. 2015, 28, 538-543. [CrossRef] [PubMed]

108. Dong, W.; Wang, Q.; Chen, J.; Zhang, L. Apparent total tract digestibility of nutrients and the digestible and metabolizable energy values of five unconventional feedstuffs fed to growing pigs. J. Appl. Anim. Res. 2019, 47, 273-379. [CrossRef]

109. Chen, G.; Shui, S.; Chai, M.; Wang, D.; Su, Y.; Wu, H.; Sui, X.; Yin, Y. Effects of Paper Mulberry (Broussonetia papyrifera) Leaf Extract on Growth Performance and Fecal Microflora of Weaned Piglets. Biomed. Res. Int. 2020, 2020, 6508494. [CrossRef] [PubMed]

110. Liu, Y.Y.; Li, Y.H.; Peng, Y.L.; He, J.H.; Xiao, D.F.; Chen, C.; Li, F.N.; Huang, R.L.; Yin, Y.L. Dietary mulberry leaf powder affects growth performance, carcass traits and meat quality in finishing pigs. J. Anim. Physiol. Anim. Nutr. 2019, 103, 1934-1945. [CrossRef]

111. Zhang, X.; Zhu, S.Z.; Yang, Q.; Su, Z.X.; Tan, H.; Liu, C.F.; Wu, M.S.; Duan, Y.H.; Yin, Y.L. Effects of broussonetia papyrifera fermented diet on growth performance, carcass quality and meat quality of Xiangsha pigs commercial line of commercial pigs. Chin. J. Anim. Nutr. 2019, 31, 5760-5771. (In Chinese)

112. Lin, Y.; Li, L.J.; Li, Y.; Wang, K.; Wei, D.Q.; Xu, S.Y.; Feng, B.; Che, L.Q.; Fang, Z.F.; Li, J.; et al. Interpretation of Fiber Supplementation on Offspring Testicular Development in a Pregnant Sow Model from a Proteomics Perspective. Int. J. Mol. Sci. 2019, 20, 4549. [CrossRef] [PubMed]

113. Li, Y.; Liu, H.Y.; Zhang, L.J.; Yang, Y.; Lin, Y.; Zhuo, Y.; Fang, Z.F.; Che, L.Q.; Feng, B.; Xu, S.Y.; et al. Maternal Dietary Fiber Composition during Gestation Induces Changes in Offspring Antioxidative Capacity, Inflammatory Response, and Gut Microbiota in a Sow Model. Int. J. Mol. Sci. 2019, 21, 31. [CrossRef] [PubMed]

114. Li, Y.; Zhang, L.J.; Liu, H.Y.; Yang, Y.; He, J.Q.; Cao, M.; Yang, M.; Zhong, W.; Lin, Y.; Zhuo, Y.; et al. Effects of the Ratio of Insoluble Fiber to Soluble Fiber in Gestation Diets on Sow Performance and Offspring Intestinal Development. Animals 2019, 9 , 422. [CrossRef] [PubMed]

115. Fan, L.J.; Huang, R.H.; Wu, C.W.; Cao, Y.; Du, T.R.; Pu, G.; Wang, H.; Zhou, W.D.; Li, H.P.; Kim, S.W. Defatted rice bran supplementation in diets of finishing pigs: Effects on physiological, intestinal barrier, and oxidative stress parameters. Animals 2020, 10, 449. [CrossRef] [PubMed]

116. Liotta, L.; Chiofalo, V.; Lo Presti, V.; Chiofalo, B. In Vivo Performances, Carcass Traits, and Meat Quality of Pigs Fed Olive Cake Processing Waste. Animals 2019, 9, 1155. [CrossRef] [PubMed]

117. Sorhue, U.G.; Ikenna, O.; Ifeanyichukwu, U.; Udeh, I.; Moemeka, M.A.; Onainor, E.R. Late-Breaking: Expression of Growth hormone Gene (GH) and Insulin-like growth factor (IGF-2) in metabolic tissues of pigs are affected by unconventional dietary feed sources. J. Anim. Sci. 2020, 97, 42-43. [CrossRef] 
118. Rho, Y.; Wey, D.; Zhu, C.; Kiarie, E.; Moran, K.; van Heugten, E.; de Lange, C.F. Growth performance, gastrointestinal and digestibility responses in growing pigs when fed corn-soybean meal-based diets with corn DDGS treated with fiber degrading enzymes with or without liquid fermentation. J. Anim. Sci. 2018, 96, 5188-5197. [CrossRef]

119. Sehm, J.; Lindermayer, H.; Dummer, C.; Treutter, D.; Pfaffl, M.W. The influence of polyphenol rich apple pomace or red-wine pomace diet on the gut morphology in weaning piglets. J. Anim. Physiol. Anim. Nutr. 2007, 91, 289-296. [CrossRef] [PubMed]

120. Fang, J.; Cao, Y.; Matsuzaki, M.; Suzuki, H.; Kimura, H. Effects of apple pomace-mixed silage on growth performance and meat quality in finishing pigs. Anim. Sci. J. 2016, 87, 1516-1521. [CrossRef] [PubMed]

121. Viveros, A.; Chamorro, S.; Pizarro, M.; Arija, I.; Centeno, C.; Brenes, A. Effects of dietary polyphenol-rich grape products on intestinal microflora and gut morphology in broiler chicks. Poult. Sci. 2011, 90, 566-578. [CrossRef] [PubMed]

122. Francesch, A.; Cartañà, M. The effects of grape seed in the diet of the Penedes chicken, on growth and on the chemical composition and sensory profile of meat. Br. Poult. Sci. 2015, 56, 477-485. [CrossRef]

123. Hughes, R.J.; Brooker, J.D.; Smyl, C. Growth rate of broiler chickens given condensed tannins extracted from grape seed. Aust. Poult. Sci. Symp. 2005, 17, 65-68.

124. Brenes, A.; Viveros, A.; Goñi, I.; Centeno, C.; Saura-calixto, F.; Arija, I. Effect of grape seed extract on growth performance, protein and polyphenol digestibilities, and antioxidant activity in chickens. Span. J. Agric. Res. 2010, 8, 326-333. [CrossRef]

125. Zhai, S.; Li, M.; Li, M.; Zhang, X.; Ye, H.; Lin, Z.; Wang, W.; Zhu, Y.; Yang, L. Effect of dietary Moringa stem meal level on growth performance, slaughter performance and serum biochemical parameters in geese. J. Anim. Physiol Anim. Nutr. 2020, 104, 126-135. [CrossRef] [PubMed]

126. Lombardi, P.; Addeo, N.F.; Panettieri, V.; Musco, N.; Pic-colo, G.; Vas-salotti, G.; Nizza, A.; Moniello, G.; Bovera, F. Blood profile and productive per-formance after partial substitu-tion of maize grain with an-cient wheat lines by-products in organic laying hens' diet. Res. Vet Sci. 2020, 133, 232-238. [CrossRef]

127. Puertas, G.; Vázquez, M. Advances in techniques for reducing cholesterol in egg yolk: A review. Crit. Rev. Food Sci. Nutr. 2019, 59, 2276-2286. [CrossRef]

128. Omri, B.; Larbi Manel, B.; Jihed, Z.; Durazzo, A.; Lucarini, M.; Romano, R.; Santini, A.; Abdouli, H. Effect of a combination of fenugreek seeds, linseeds, garlic and copper sulfate on laying hens performances, egg physical and chemical qualities. Foods 2019, 8, 311. [CrossRef]

129. Gurbuz, Y.; Salih, Y.G. Influence of sumac (Rhus coriaria L.) and ginger (Zingiber officinale) on egg yolk fatty acid, cho-lesterol and blood parameters in laying hens. J. Anim. Physiol. Anim. Nutr. 2017, 101, 1316-1323. [CrossRef]

130. Nunes, K.C.; Eyng, C.; Pintro, P.T.M.; Garcia, R.G.; Murakami, A.E.; Vital, A.C.P.; Nunes, R.V.; Nesello, P.O. Dietary inclusion of dehydrated bocaiuva pulp increases the antioxidant potential of quail eggs. J. Anim. Physiol. Anim. Nutr. 2018, $103,64-71$. [CrossRef]

131. Saeed, M.; Abbas, G.; Alagawany, M.; Kamboh, A.A.; Abd El-Hack, M.E.; Khafaga, A.F.; Chao, S. Heat stress management in poultry farms: A comprehensive overview. J. Therml. Biol. 2019, 84, 414-425. [CrossRef]

132. Rowland, L.A.; Bal, N.C.; Periasamy, M. The role of skeletal-muscle-based thermogenic mechanisms in vertebrate endothermy. Biol. Rev. 2015, 90, 1279-1297. [CrossRef]

133. Nawab, A.; Ibtisham, F.; Li, G.; Kieser, B.; Wu, J.; Liu, W.; Zhao, Y.; Nawab, Y.; Li, K.; Xiao, M.; et al. Heat stress in poultry production; Mitigation strategies to overcome the future challenges facing the global poultry industry. J. Therml. Biol. 2018, 78, 131-139. [CrossRef]

134. Reis, J.H.; Gebert, R.R.; Barreta, M.; Boiago, M.M.; Souza, C.F.; Baldissera, M.D.; Santos, I.D.; Wagner, R.; Laporta, L.V.; Stefani, L.M.; et al. Addition of grape pomace flour in the diet on laying hens in heat stress: Impacts on health and performance as well as the fatty acid profile and total antioxidant capacity in the egg. J. Therml. Biol. 2019, 80, 141-149. [CrossRef]

135. Zhao, J.S.; Deng, W.; Liu, H.W. Effects of chlorogenic acid-enriched extract from Eucommia ulmoides leaf on performance, meat quality, oxidative stability, and fatty acid profile of meat in heat-stressed broilers. Poult. Sci. 2019, 98, 3040-3049. [CrossRef] [PubMed]

136. Hosseini-Vashan, S.J.; Golian, A.; Yaghobfar, A. Growth, immune, antioxidant, and bone responses of heat stress-exposed broilers fed diets supplemented with tomato pomace. Int. J. Biometeorol. 2015, 60, 1183-1192. [CrossRef]

137. Iqbal, M.W.; Zhang, Q.; Yang, Y.B.; Zou, C.X.; Li, L.L.; Liang, X.; Wei, S.J.; Lin, B. Ruminal fermentation and microbial community differently influenced by four typical subtropical forages in vitro. Anim. Nutr. 2018, 4, 100-108. [CrossRef]

138. Nayan, N.; van Erven, G.; Kabel, M.A.; Sonnenberg, A.S.; Hendriks, W.H.; Cone, J.W. Improving ruminal digestibility of various wheat straw types by white-rot fungi. J. Sci. Food Agric. 2019, 99, 957-965. [CrossRef] [PubMed]

139. Babaeinasab, Y.; Rouzbehan, Y.; Fazaeli, H.; Rezaei, J. Chemical composition, silage fermentation characteristics, and in vitro ruminal fermentation parameters of potato-wheat straw silage treated with molasses and lactic acid bacteria and corn silage. $J$. Anim. Sci. 2015, 93, 4377-4386. [CrossRef]

140. Zhang, M.; Lv, H.X.; Tan, Z.F.; Li, Y.; Wang, Y.P.; Pang, H.L.; Li, Z.W.; Jiao, Z.; Jin, Q.S. Improving the fermentation quality of wheat straw silage stored at low temperature by psychrotrophic lactic acid bacteria. Anim. Sci. J. 2017, 88, 277-285. [CrossRef] [PubMed]

141. Amaral, F.P.; Grazziotin, R.C.B.; Machado, M.C.; Hasse, L.; Frata, M.; Blanco, C.S.; Goncalves, F.M.; Ribeiro-Filho, H.M.N.; Bermudes, R.F.; Del Pino, F.A.B.; et al. Limits of grape by-product inclusion in diets for lambs: Zinc supplementation to prevent copper poisoning. Res. Vet. Sci. 2019, 124, 334-337. [CrossRef] 
142. Mokni, M.; Amri, M.; Limam, F.; Aouani, E. Effect of grape seed and skin supplement on milk yield and composition of dairy ewes. Trop. Anim. Health Prod. 2016, 49, 131-137. [CrossRef]

143. Chikwanha, O.C.; Muchenje, V.; Nolte, J.E.; Dugan, M.E.R.; Mapiye, C. Grape pomace (Vitis vinifera L. cv. Pinotage) supplementation in lamb diets: Effects on growth performance, carcass and meat quality. Meat Sci. 2019, 147, 6-12. [CrossRef] [PubMed]

144. Gómez-Cortés, P.; Guerra-Rivas, C.; Gallardo, B.; Lavín, P.; Mantecón, A.R.; de la Fuente, M.A.; Manso, T. Grape pomace in ewes diet: Effects on meat quality and the fatty acid profile of their suckling lambs. Food Res. Int. 2018, 113, 36-42. [CrossRef]

145. Gao, X.; Tang, F.; Zhang, F.; Jia, C.; Yang, Z.; Liu, C.; Gao, W. Effects of the supplementation of distillers' grape residues on ruminal degradability, whole tract digestibility and nitrogen metabolism in sheep. Arch Anim. Nutr. 2019, 73, 384-398. [CrossRef] [PubMed]

146. Moate, P.J.; Williams, S.R.O.; Torok, V.A.; Hannah, M.C.; Ribaux, B.E.; Tavendale, M.H.; Eckard, R.J.; Jacobs, J.L.; Auldist, M.J.; Wales, W.J. Grape marc reduces methane emissions when fed to dairy cows. J. Dairy Sci. 2014, 97, 5073-5087. [CrossRef]

147. Chedea, V.S.; Pelmus, R.S.; Lazar, C.; Pistol, G.C.; Calin, L.G.; Toma, S.M.; Dragomir, C.; Taranu, I. Effects of a diet containing dried grape pomace on blood metabolites and milk composition of dairy cows. J. Sci. Food Agric. 2016, 97, 2516-2523. [CrossRef] [PubMed]

148. Iannaccone, M.; Elgendy, R.; Giantin, M.; Martino, C.; Giansante, D.; Ianni, A.; Dacasto, M.; Martino, G. RNA Sequencing-Based Whole-Transcriptome Analysis of Friesian Cattle Fed with Grape Pomace-Supplemented Diet. Animals 2018, 8, 188. [CrossRef] [PubMed]

149. Dos, S.F.H.B.; Véras, R.M.L.; de Andrade Ferreira, M.; de Lima Silva, J.; de Vasconcelos, G.A.; Soares, L.F.P.; Cardoso, D.B. Liquid residue of cassava as a replacement for corn in the diets of sheep. Trop. Anim. Health Prod. 2015, 47, 1083-1088.

150. Pilajun, R.; Wanapat, M. Growth performance and carcass characteristics of feedlot Thai native $\times$ Lowline Angus crossbred steer fed with fermented cassava starch residue. Trop. Anim. Health Prod. 2016, 48, 719-726. [CrossRef]

151. Angulo, J.; Mahecha, L.; Yepes, S.A.; Yepes, A.M.; Bustamante, G.; Jaramillo, H.; Valencia, E.; Villamil, T.; Gallo, J. Nutritional evaluation of fruit and vegetable waste as feedstuff for diets of lactating Holstein cows. J. Environ. Manag. 2012, 95, S210-S214. [CrossRef]

152. Tayengwa, T.; Chikwanha, O.C.; Dugan, M.E.R.; Mutsvangwa, T.; Mapiye, C. Influence of feeding fruit by-products as alternative dietary fibre sources to wheat bran on beef production and quality of Angus steers. Meat Sci. 2020, 161, 107969. [CrossRef] [PubMed]

153. De Evan, T.; Cabezas, A.; de la Fuente, J.; Carro, M.D. Feeding agroindustrial by-products to light lambs: Influence on growth performance, diet digestibility, nitrogen balance, ruminal fermentation, and plasma metabolites. Animals 2020, 10, 600. [CrossRef] [PubMed]

154. Froetschel, M.A.; Ross, C.L.; Stewart, R.L., Jr.; Azain, M.J.; Michot, P.; Rekaya, R. Nutritional value of ensiled grocery food waste for cattle. J. Anim. Sci. 2014, 92, 5124-5133. [CrossRef] [PubMed]

155. Smith, P.M.; Bustamante, H.; Ahammad, H.; Clark, H.; Dong, E.; Elsiddig, H.; Haberl, R.; Harper, J.; House, M.; Jafari, O.; et al. Agriculture, Forestry and Other Land Use (AFOLU). In Climate Change 2014: Mitigation of Climate Change; Cambridge University Press: Cambridge, UK; New York, NY, USA, 2014; pp. 811-922. Available online: http:/ / mitigation2014.org/ (accessed on 22 February 2021).

156. Vasta, V.; Daghio, M.; Cappucci, A.; Buccioni, A.; Serra, A.; Viti, C.; Mele, M. Invited review: Plant polyphenols and rumen microbiota responsible for fatty acid biohydrogenation, fiber digestion, and methane emission: Experimental evidence and methodological approaches. J. Dairy Sci. 2019, 102, 3781-3804. [CrossRef] [PubMed]

157. Van Wesemael, D.; Vandaele, L.; Ampe, B.; Cattrysse, H.; Duval, S.; Kindermann, M.; Fievez, V.; De Campeneere, S.; Peiren, N. Reducing enteric methane emissions from dairy cattle: Two ways to supplement 3-nitrooxypropanol. J. Dairy Sci. 2018, 102, 1780-1787. [CrossRef] [PubMed]

158. Kliem, K.E.; Humphries, D.J.; Kirton, P.; Givens, D.I.; Reynolds, C.K. Differential effects of oilseed supplements on methane production and milk fatty acid concentrations in dairy cows. Animals 2019, 13, 309-317. [CrossRef] [PubMed]

159. Lozano, A.; Uclés, S.; Uclés, A.; Ferrer, C.; Fernández-Alba, A.R. Pesticide Residue Analysis in Fruit- and Vegetable-Based Baby Foods Using GC-Orbitrap MS. J. AOAC Int. 2018, 101, 374-382. [CrossRef] 